\title{
Spór kanonika Wernera von Czettritz z klasztorem św. Macieja we Wroclawiu - proces sądowy w Rocie Rzymskiej i jego dokumentacja źródłowa
}

\begin{abstract}
Zarys treści: Artykuł opisuje spór sądowy z lat 1373-1383 między klasztorem św. Macieja we Wrocławiu, zakonu krzyżowców z Czerwoną Gwiazdą, a kanonikiem wrocławskim Wernerem von Czettritz o prawo do korzystania z rzeki Oławy. Proces toczył się najpierw we Wrocławiu, a po apelacji trafił do Roty Rzymskiej (1375-1383) i pozostał po nim wyjątkowy komplet źródeł. Omówiono dokumenty związane z procesem, zarówno te wytworzone w samej Rocie (dokumenty audytorów), jak i te związane z postępowaniem egzekucyjnym, a także przeanalizowano wartość różnych typów dokumentów z punktu widzenia historyka.
\end{abstract}

\begin{abstract}
The article describes the lawsuit of 1373-1383 between the monastery of St Matthias in Wrocław belonging to the Brethren (Knights) of the Cross with the Red Star and a Wrocław canon Werner von Czettritz over the right to use the Olawa River. The suit was first filed before the court in Wrocław, and then, after an appeal, it was brought to the Roman Rota (1375-1383); it has left an outstanding set of written sources. The author discusses the documents related to the lawsuit, both those issued by the Rota (auditors' documents), and those related to the enforcement proceedings, and he analyses the value of various types of documents from the historian's perspective.
\end{abstract}

Słowa kluczowe: Rota Rzymska, klasztor św. Macieja we Wrocławiu, krzyżowcy z Czerwoną Gwiazdą, Werner von Czettritz, dokumenty audytorów, papieski sędzia delegowany, Księże Małe

Keywords: Roman Rota, St Matthias' monastery in Wrocław, Brethren (Knights) of the Cross with the Red Star, Werner von Czettritz, auditor's document, papal delegated judge, Księże Małe

Na początku lat 70. XIV w. wybuchł konflikt między klasztorem (szpitalem) św. Macieja we Wrocławiu, zakonu krzyżowców z Czerwoną Gwiazdą, a kanonikiem wrocławskim Wernerem von Czettritz o prawo do korzystania z rzeki Oławy na odcinku rozgraniczającym ich dobra ${ }^{1}$. W tej dość banalnej sprawie między zwaśnionymi stronami wywiązał się wieloletni spór sądowy, który z czasem trafił do trybunału Roty Rzymskiej. Po skomplikowanym postępowaniu pozostała wyjątkowo dobrze zachowana spuścizna źródłowa, w formie kilkunastu bardzo obszernych dokumentów. Daje to możliwość odtworzenia przebiegu ciekawego procesu z dokładnością zwykle niedostępną. Wraz z opisem procesu w Rocie przedstawione zostaną związane z nim dokumenty, które zwykle sprawiają sporo problemów

\footnotetext{
${ }^{1}$ Składam wyrazy podziękowania panom prof. Wacławowi Uruszczakowi i prof. Maciejowi Mikule z Uniwersytetu Jagiellońskiego za wyjaśnienia dotyczące wielu kwestii natury prawnej i terminologii prawniczej.
} 
historykom. W niniejszym artykule zostaną omówione źródła zarówno wytworzone w samej Rocie (dokumenty audytorów), jak i te będące konsekwencją postępowania przed papieskim trybunałem, a związane z postępowaniem egzekucyjnym ${ }^{2}$. Dla łatwiejszej orientacji w tekście wprowadzone zostały śródtytuły, które w zasadniczej części artykułu odpowiadają kolejnym etapom omawianego sporu. W naturalny sposób będą one kierować uwagę na przebieg procesu sądowego, ale należy pamiętać, że równie istotna jest analiza wytworzonych przy tej okazji źródeł. Aby właściwie zrozumieć kontekst, w jakim powstały i funkcjonowały wspomniane dokumenty, należy pokrótce przedstawić sam papieski trybunał Roty Rzymskiej.

\section{Papieski trybunal Roty Rzymskiej}

Od XIII w., wraz ze wzrostem znaczenia papiestwa i postępującą centralizacją Kościoła, duchowni i świeccy z całej Europy coraz częściej zwracali się do Stolicy Apostolskiej w różnego rodzaju kwestiach prawnych. W drodze stopniowej ewolucji wykształcił się najwyższy trybunał w Kościele katolickim, który z czasem przyjął nazwę Sacra Romana Rota. Przełomowym momentem w dziejach Roty Rzymskiej była konstytucja papieża Jana XXII Ratio iuris z 1331 r. Nadała ona temu sądowi kształt, który w zasadniczym zrębie przetrwał przez wieki. Rota stała się najwyższym kościelnym trybunałem apelacyjnym dla całego zachodniego chrześcijaństwa ${ }^{3}$. Badania naukowe nad Rotą Rzymską biegły dwutorowo. Z natury rzeczy przede wszystkim była przedmiotem zainteresowania kanonistów, którzy koncentrowali się na ściśle prawnych aspektach zagadnienia. Później badania podjęli też historycy, którzy zajęli się takimi zagadnieniami, jak zasięg i skala oddziaływania Roty, czas trwania procesów itp. Silnym impulsem do podjęcia przez historyków studiów nad Rotą było otwarcie dla badaczy Archiwum Watykańskiego w 1880 r. przez papieża Leona XIII ${ }^{4}$. Po pierwszej fali badań nastąpił długi okres zastoju. Wyraźniejsze ożywienie daje się zauważyć około początku obecnego stulecia (Per Ingesman, Stefan Killermann, Kirsi Salonen $)^{5}$. Rota pozostaje jednak ciągle chyba najsłabiej przebadanym organem papieskiej kurii z czasów średniowiecza. Nietrudno wyjaśnić przyczyny takiego stanu rzeczy. Pierwszą jest skomplikowanie samej materii, jaką jest średniowieczne prawo kanoniczne, drugą zaś stan zachowania źródeł i ich specyfika. Aż do schyłku XV w. historycy skazani są na materiały zachowane w archiwach odbiorców, względnie nieliczne, rozproszone i zwykle niewydane. Dla okresu późniejszego posiadamy źródła z archiwum Roty, które są ogromną masą akt, trudną do ogarnięcia przez badaczy. Kłopoty pojawiają się nawet na najbardziej podstawowym poziomie, bo sam tekst rękopiśmienny jest niełatwy paleograficznie. Problemów przysparza też język źródła (żargon prawniczy), trudno zrozumiały dla historyka, który nie jest kanonistą.

\footnotetext{
${ }^{2}$ Ze względu na brak opracowań dotyczących omawianej problematyki, będę się opierał przede wszystkim na źródłach. Przywoływane w tym artykule dokumenty dotyczące procesu toczonego przez wrocławski klasztor św. Macieja przechowywane są w Archiwum Państwowym we Wrocławiu. Niemal wszystkie w najbliższym czasie zostaną przeze mnie opublikowane w tomie: Monumenta Vaticana res gestas Polonicas illustrantia, t. 1: Acta Urbani VI papae (1378-1389). Z powodu bardzo dużych rozmiarów wielu dokumentów obok sygnatury archiwalnej w przypisach będę podawał też numery wierszy, w których znajduje się odpowiednia informacja.

${ }^{3}$ K. Salonen, Papal Justice in the Late Middle Ages. The Sacra Romana Rota, London-New York 2016, s. 16 n.; H. Hoberg, Inventario dell'archivio della Sacra Romana Rota (sec. XIV-XIX), oprac. J. Metzler, Città del Vaticano 1994, s. 15-18 (tam dalsza literatura).

${ }^{4}$ Za najważniejszą pracę z wykorzystaniem archiwaliów watykańskich, spośród powstałych pod koniec XIX i na początku XX w., uważa się studium: N. Hilling, Die römische Rota und das Bistum Hildesheim am Ausgange des Mittelalters (1464-1513). Hildesheimische Prozeßakten aus dem Archiv der Rota zu Rom, Münster 1908.

${ }_{5}^{5}$ Stan badań nad Rotą Rzymską przedstawiła ostatnio K. Salonen, Papal Justice, s. 9-12. Autorka koncentruje się głównie na pracach o charakterze historycznym, opartych na materiałach z Archiwum Watykańskiego. Zob. też Ch. Bukowska-Gorgoni, Causae Polonae coram Sacra Romana Rota. XV-XVII saec. Explanatio processuum et regesta documentorum, Roma 1995, s. 1-44. Dawniejsza literatura zestawiona w: W. Nachtman, Trybunat Roty Rzymskiej. Historia, organizacja, postepowanie, Lublin 1957.
} 
Na uwagę zasługuje najnowsza książka fińskiej badaczki K. Salonen ${ }^{6}$. W przeciwieństwie do wcześniejszych historyków, którzy bazowali na materiale mocno ograniczonym czasowo lub geograficznie, autorka oparła swe wnioski na dużej próbie źródeł z archiwum Roty z lat 1466-1526 (5439 spraw). Pozwoliło jej to zweryfikować, a niekiedy podważyć ustalenia poprzedników (Nikolausa Hillinga, Hermanna Hoberga, Gerona Dolezaleka, Pera Ingesmana). Warto przytoczyć tu niektóre jej wnioski. Jeśli chodzi o rodzaj rozpatrywanych spraw, to sprawy beneficjalne stanowiły $80 \%$, własnościowe $14 \%$, małżeńskie $1 \%$, inne zaś $5 \%{ }^{7}$. Przez „sprawy własnościowe” rozumie się tu spory o tytuł własności, dochody i czasem długi. W przybliżeniu odpowiada to wcześniejszym ustaleniom historyków. Patrząc na pochodzenie geograficzne spraw podejmowanych w Rocie, najwięcej pochodziło z Italii (31\%) i Półwyspu Iberyjskiego (28\%), następnie z Cesarstwa (20\%) i Francji (18\%), natomiast z Europy Wschodniej tylko 2\%, z Wysp Brytyjskich 1\%, a Skandynawia była praktycznie nieobecna ${ }^{8}$. W miarę upływu lat widoczne są pewne zmiany na korzyść Włoch i Półwyspu Iberyjskiego, kosztem Cesarstwa i Francji. Wśród stosunkowo niewielkiej liczby spraw z Europy Wschodniej sprawy beneficjalne stanowiły 79\%, własnościowe $10 \%$, małżeńskie $2 \%$, a inne $9 \%{ }^{9}$. Bardzo ciekawe są ustalenia odnoszące się do czasu trwania procesów w Rocie Rzymskiej. W historiografii powszechnie uważano, że sąd papieski był wyjątkowo nieskuteczny, a przeciętny proces ciągnął się latami. Potwierdzały to ustalenia N. Hillinga, opierające się na materiale dotyczącym diecezji Hildesheim ${ }^{10}$. Analiza rękopisów z serii Manualia actorum pokazała, że 46\% procesów dobiegało końca przed upływem miesiąca, kolejne 10\% trwało nie więcej niż 2 miesiące, a następne 5\% nie więcej niż kwartał. Tylko 10,5\% ogółu postępowań stanowiły sprawy osądzone w ciągu 13-24 miesięcy, a zaledwie 3,5\% wszystkich procesów ciągnęło się dłużej niż 2 lata ${ }^{11}$. Należy pamiętać, że większość procesów nie kończyła się wyrokiem, ale była przerywana $\mathrm{w}$ trakcie procedowania. Wielu uczestników postępowania wycofywało się ze sporu, a nierzadko strony zawierały ugodę poza sądem ${ }^{12}$. Na usprawiedliwienie dotychczasowych poglądów trzeba zauważyć, że przekonanie o przewlekłości procesów przed papieskim trybunałem nie wzięło się znikąd. Pisali o tym nierzadko współcześni ${ }^{13}$, a wielokrotnie poświadczały to źródła. Choć bowiem zdecydowana większość postępowań w Rocie dotyczyła spraw beneficjalnych, to dla okresu sprzed schyłku XV w. (gdy nie ma zachowanego archiwum Roty) obraz papieskiego trybunału kształtują źródła $\mathrm{z}$ archiwów krajowych, gdzie sprawy własnościowe stanowią zasadniczą część. Wynika to z faktu, że w archiwach odbiorców przechowywano głównie dokumenty o ważności wieczystej, jakimi są przede wszystkim tytuły własności ${ }^{14}$. Ponadto zachowany materiał dotyczy w znacznej mierze tych sporów o własność, które zakończyły się wyrokiem, a więc trwały odpowiednio długo.

Polska historiografia nie zajmowała się dotąd prawie w ogóle średniowieczną Rotą Rzymską. Jedynym wyjątkiem jest wydana w Rzymie w 1995 r. książka Krystyny Bukowskiej-Gorgoni, poświęcona sprawom polskim w trybunale Roty w XV-XVII w. ${ }^{15}$ Praca składa się z liczącego 66 stron „Wprowadzenia", w którym naszkicowane zostały dzieje Roty, jej kompetencje i przebieg procesu sądowego, oraz liczącej 450 stron części źródłowej, przy czym materiał średniowieczny (do 1500) to zaledwie

\footnotetext{
${ }^{6}$ K. Salonen, Papal Justice.

7 Tamże, s. 99-105.

8 Tamże, s. 125-134.

9 Tamże, s. 150.

${ }^{10}$ N. Hilling, Die römische Rota, s. 55 n.

${ }^{11}$ K. Salonen, Papal Justice, s. 160 (wykres 10.1).

12 Tamże, s. 167 n.

${ }^{13}$ K. Salonen przypuszcza, że wiele wzmianek o przeciągających się procesach miało tylko charakter zwrotów zwyczajowych, bez podania konkretnego czasu trwania procesu; tamże, s. 156.

${ }^{14}$ Procesy o beneficja znane są dzięki bullom egzekucyjnym, których kopie znajdują się w registrach kancelaryjnych. Część registrów jednak zaginęła, a wiele procesów w Rocie kończyło się przed wydaniem wyroku, więc bulli nie wystawiano.

${ }^{15}$ Ch. Bukowska-Gorgoni, Causae Polonae. Pewną przydatność zachowuje syntetyczne opracowanie ks. W. Nachtmana sprzed 60 lat. Ta niewielka praca obejmuje dzieje Roty aż do połowy XX w., a średniowieczu poświęcone są tylko małe fragmenty; zob. tenże, Trybunat Roty Rzymskiej.
} 
6 stron (3 sprawy). Część źródłowa nie jest jednak edycją, ale czymś w rodzaju wykazu poloników $\mathrm{z}$ archiwum papieskiego trybunału, z przedstawieniem ich treści (po łacinie). Sama autorka odmawia swym wypisom miana regestów. Zebrane zapiski ukazują przebieg postępowania przed papieskim sądem w kolejnych sprawach. Autorka świadomie nie wykorzystała jednak archiwaliów z najstarszej i najobszerniejszej serii Manualia actorum et citationum, gdzie znajduje się dużo poloników ${ }^{16}$. Podczas kwerendy w średniowiecznej części zespołów Commissiones i Sententiae również znalazłem pominięte zapiski dotyczące Polski.

Polski historyk dysponuje niedużą liczbą wydanych drukiem dokumentów związanych z procesem w Rocie. Wydawcy kodeksów dyplomatycznych z niechęcią patrzyli na długie i trudne teksty, często rezygnując z ich publikacji ${ }^{17}$. Ich stosunek do tego typu źródeł najlepiej ilustruje komentarz zasłużonego wydawcy, prof. Stanisława Kurasia, który wyjaśniał, czemu dokumenty z Roty drukuje tylko w regestach: „wyroki Kurii papieskiej cechują się niezmierną rozwlekłością i wielkim ubóstwem treści”18. Wydawcy mieli też nierzadko problemy z regestowaniem tych specyficznych źródeł ${ }^{19}$. Na usprawiedliwienie można dodać, że ze względu na swoją wielkość oraz stosowany w nich żargon prawniczy dokumenty rotalne są bardzo niewygodne w czytaniu i trudne do zrozumienia, jeśli nie zna się ich struktury. Regesty licznych bulli egzekucyjnych do wyroków audytorów, wydane w Bullarium Poloniae, są całkowicie nieprzydatne dla badania Roty.

\section{Źródła rotalne - archiwum Roty}

Niniejszy artykuł dotyczy procesu w Rocie Rzymskiej, który toczył się w ostatniej ćwierci XIV w., rozważania oparte są więc na materiale z archiwów krajowych. Najważniejszym typem źródeł powstających przy okazji procesu są dokumenty wystawiane przez papieskich audytorów, zawierające wydane przez nich wyroki. Aby jednak dobrze zrozumieć, czym są owe dokumenty, przydatne będzie krótkie przedstawienie dokumentacji przechowywanej w archiwum najwyższego kościelnego trybunału. Zachowane akta Roty Rzymskiej sięgają schyłku XV stulecia. Przed 1500 r. zaczynają się trzy serie archiwaliów: Commissiones (od 1480), Manualia actorum et citationum (od 1464) oraz Sententiae (od 1474) ${ }^{20}$. $\mathrm{W}$ serii Commissiones znajdują się oryginalne supliki kierowane do papieża w związku z procesem. Są to papierowe karty, o wielkości zależnej od długości supliki, ale najczęściej są zbliżone do dzisiejszego formatu A5 (połowa karty formatu folio). Przechowywane są w archiwum Roty w formie powiązanych tasiemką plików. W dokumentach audytorów określane są one jako supplicationis seu commissionis cedulae, czyli supliki-zlecenia. Ta nieco zaskakująca nazwa jest efektem stosowanej procedury. Aby wszcząć proces w Rocie, zainteresowany musiał najpierw złożyć suplikę do papieża. Podawano w niej podstawowe informacje na temat sporu, takie jak: strony sporu, jego przedmiot, okoliczności wybuchu konfliktu, powód skierowania sprawy do Roty itp. Kiedy sam papież lub wicekanclerz pozytywnie rozpatrzył prośbę, była ona sygnowana. W formule wpisywanej bezpośrednio pod tekstem supliki wskazywany był konkretny audytor Roty, któremu zlecano sprawę. W najprostszej formie sygnatura miała postać: „Audiat magister NN [nazwisko audytora - M.D.K.] et iusticiam faciat”, choć zwykle dodawane

\footnotetext{
16 Jako powód pominięcia Manualiów autorka wskazała wielką liczbę tomów w tej serii i trudności paleograficzne; Ch. Bukowska-Gorgoni, Causae Polonae, s. 46 n., 62.

17 Zob. np. KDKK, t. 2, nr 405, gdzie wydawcy zamieścili tylko wzmiankę, czego dotyczy „długa ta bulla” z 13 XII 1395 , czyli bulla egzekucyjna Bonifacego IX, po czym podali daty trzech wyroków z Roty oraz dokumentu wystawionego przez egzekutora. Żadnego z tych pięciu dokumentów, których oryginały znajdowały się wtedy w archiwum katedry krakowskiej, nie ma dziś w tamtejszym zbiorze pergaminów.

${ }_{18}$ Zbiór dokumentów katedry i diecezji krakowskiej, t. 1, wyd. S. Kuraś, Lublin 1965 [dalej: ZDKK], s. V.

19 Zob. regesty dokumentów: KDWlkp., t. 9, nr 1111, 1143, gdzie dyspozycję w litterae compulsoriae enigmatycznie wyjaśniono jako ,polecenie przeprowadzenia postępowania sądowego”; zob. niżej, przyp. 35.

${ }^{20}$ Inwentarz archiwum Roty: H. Hoberg, Inventario. Seria Processus in admissione auditorum zaczyna się w 1492 r., ale nie dotyczy spraw sądowych.
} 
były jeszcze inne klauzule ${ }^{21}$. W ten sposób suplika przekształcała się w commissio skierowaną do audytora. Suplika nie była datowana ani wpisywana do registrów kancelaryjnych (Registra supplicationum). $\mathrm{Na}$ odwrocie prośby podawano nazwę sprawy (np. „Plocensis prepositure”), imię posłańca (cursor) doręczającego zlecenie audytorowi i datę doręczenia, będącą równocześnie datą rozpoczęcia procesu sądowego ${ }^{22}$. W XIV i XV w. należało uzyskać osobną commissio dla każdej czynności procesowej, w jednej sprawie mogło ich więc być nawet kilkadziesiąt. Zmienił to dopiero Innocenty VIII w $1487 \mathrm{r}^{23}$ Owe kolejne commissiones nie zawierają zwykle informacji cennych dla historyka, bo dotyczyły np. prolongaty terminów.

Seria Manualia actorum et citationum gromadzi kodeksy stanowiące własność notariuszy (każdy z co najmniej 12 audytorów Roty miał 4 notariuszy) ${ }^{24}$. Wpisywali oni do tych ksiąg informacje o kolejnych sesjach sądu i innych krokach w procesie „swojego” audytora (np. doręczenie przez posłańca nowej commissio i wszczęcie procesu, wezwanie stron do przedłożenia dowodów, itp.). Wpisy były krótkie i informowały wyłącznie o formalnej stronie postępowania. Datowane zapiski wnoszono w kolejności chronologicznej, bez względu na to, do którego z prowadzonych równocześnie procesów się odnosiły. Dla orientacji w tym gąszczu notariusze opatrywali każdą zapiskę nagłówkiem (nazwą sprawy), a na marginesie umieszczali charakterystyczne znaki obok pierwszych i ostatnich zapisek w poszczególnych procesach ${ }^{25}$.

W serii Sententiae przechowywane są oryginały wyroków wydawanych przez audytorów Roty. Podobnie jak w przypadku commissiones, wyroki mają postać luźnych papierowych kart, które przechowywane są obecnie w związanych sznurkiem fascykułach. Na jednej stronie znajduje się tekst wyroku, pod którym jest podpis audytora, jak np.: „Ita pronunciam ego Guillermus de Pereriis auditor”26. Po drugiej zaś jest pełna formuła datacyjna, zaczynająca się od słów: „Lecta, lata et in scriptis promulgata fuit hec presens nostra diffinitiva sentencia ...", a ponadto nazwa sprawy i podpis notariusza ${ }^{27}$. Wyrok taki nie ma żadnych dodatkowych środków uwierzytelniających. Zwycięska strona musiała się więc postarać o wystawienie przez audytora dokumentu z wpisaną weń sentencją.

Większość serii zawiera jednak akta zachowane dopiero z czasów późniejszych (poczynając od XVI w.). Jedną z najważniejszych jest seria Decisiones (od 1511), w której znajdują się uzasadnienia wyroków. Ze względu na ich znaczenie dla interpretacji prawa decyzje były gromadzone, a ich zbiory krążyły wśród prawników od XIV w. W późniejszym czasie zbiory te były wydawane drukiem ${ }^{28}$. Akta przedstawiane w sądzie przez procesujące się strony, takie jak odpisy dokumentów, libelli, zarzuty i inne, najwyraźniej były zwracane stronom po zakończeniu procesu, nie zachowały się bowiem w żadnej formie ${ }^{29}$.

Łatwo zrozumieć, dlaczego przechowywano oryginalne commissiones (supliki), a nawet wyroki, bez kopiowania ich do osobnych ksiąg. Z powodu ogromnej liczby spraw załatwianych w Rocie, a tym samym napływu olbrzymiej ilości akt, wymagałoby to zatrudnienia wielu dodatkowych notariuszy.

${ }^{21} \mathrm{Na}$ przykład w pierwszej suplice w omawianym procesie: „De mandato domini nostri pape, audiat magister Nicolaus de Cremona super puncto iuris et iusticiam faciat, si causa sit magna, et citet, ut petitur”; AP Wrocław, Rep. 66, nr 299 (298) [nr 9], w. 11 n.; zob. też bardzo rozbudowaną sygnaturę w KDWlkp., t. 3, nr 1757.

22 Archivum Apostolicum Vaticanum, S. R. Rota, Commissiones, t. 1, f. 5. Na karcie zamieszczano też inne dopiski: imiona świadków doręczenia commissionis, imię notariusza, znaki kancelaryjne itd., ale nie są one istotne z punktu widzenia niniejszych rozważań. Na temat procedury zob. K. Salonen, Papal Justice, s. 42-47; Ch. Bukowska-Gorgoni, Causae Polonae, s. 17-28.

${ }^{23}$ Ch. Bukowska-Gorgoni, Causae Polonae, s. 23-26. W sporze o prepozyturę płocką wydano co najmniej 40 commissiones; tamże, s. 139-144.

${ }^{24}$ W omawianym czasie audytorów było więcej niż 12; zob. W. Nachtman, Trybunat Roty Rzymskiej, s. 50 n., $80-83$.

${ }^{25}$ Zob. K. Salonen, Papal Justice, s. 5 n. O treści zapisek i stronie graficznej rękopisów piszę na podstawie autopsji wybranych tomów z serii Manualia actorum.

${ }^{26}$ Tak np. w Archivum Apostolicum Vaticanum, S. R. Rota, Sententiae, t. 1, f. 1 (1484 r.). Być może należałoby uznać owe karty za minuty wyroków, a nie ich oryginały. Nie spotkałem jednak nigdy tekstu samego wyroku wystawionego w formie dokumentu. Jak przedstawiono niżej, treść wyroku wpisywano do obszernego dokumentu z opisem całego procesu.

27 Zob. K. Salonen, Papal Justice, s. 51-54.

${ }^{28}$ Ch. Bukowska-Gorgoni, Causae Polonae, s. 39 n., 53-59; K. Salonen, Papal Justice, s. 10.

${ }^{29}$ Akta tego typu zachowały się tylko wyjątkowo; por. A. Kozak, J. Łukaszewski, Dokumentacja konsystorska z XV i początku XVI wieku odkryta w katedrze gnieźnieńskiej, Rocz. Hist., 83, 2017, s. 211 n. 


\section{Źródła rotalne - archiwa odbiorców}

Najważniejszymi dokumentami pochodzącymi z Roty Rzymskiej, jakie można znaleźć w archiwach odbiorców, są dokumenty wystawiane przez papieskich audytorów, zawierające wydane przez nich wyroki. Są to charakterystyczne wielkie płachty pergaminu, o bokach długości $50-70 \mathrm{~cm}$, gęsto zapisane drobnym pismem. Ich objętość zwykle waha się między 20 tys. a 40 tys. znaków ${ }^{30}$. Najczęściej zachowane są w formie oryginałów, ze względu na swoją wielkość rzadko bowiem trafiały do kopiariuszy. Dokumenty tego typu już przez średniowiecznych posiadaczy były nazywane „wyrokami”. Na stronie dorsalnej często znajdujemy noty typu: „sentencia prima”, „sentencia secunda” itp. ${ }^{31}$ Należy jednak podkreślić, że dokumenty te nie są wyrokami audytorów, ale przedstawiają przebieg całego procesu, od początkowej commissionis aż do wyroku i oszacowania kosztów sądowych ${ }^{32}$. Oczywiście, choć formalnie błędne, używanie miana „sententia” jest w pełni zrozumiałe. Cały proces miał przecież na celu uzyskanie korzystnego rozstrzygnięcia, a inserowany wyrok audytora był dla posiadacza najważniejszym elementem dokumentu. Struktura typowych dokumentów jest dość podobna i wyraźnie widać, że były one redagowane na podstawie znajdujących się w Rocie materiałów procesowych. Na początku inserowana jest $\mathrm{w}$ całości commissio (suplika-zlecenie) wraz z pełną sygnaturą papieską ${ }^{33}$, chyba że dyplom dotyczył kolejnej instancji, to wtedy zamieszczano jedynie krótką informację o apelacji od poprzedniej sentencji. Choć podczas procesu wystawiano później bardzo liczne commissiones, to do dokumentu $\mathrm{z}$ wyrokiem wciągano wyjątkowo tylko te, które były istotne dla przebiegu postępowania, np. nakazujące połączenie w jedną kilku wiążących się ze sobą spraw ${ }^{34}$. Następnie wymienione są kolejne kroki postępowania sądowego, na podstawie rękopisów notariuszy Roty (z serii Manualia). Przy każdej sesji podana jest informacja, czy zastępcy procesowi (prokuratorzy) obu stron byli obecni w sądzie. W zależności od potrzeby inserowane mogły zostać także inne pisma procesowe. W omawianym procesie, w każdym z trzech dokumentów z wyrokami [nr 9, 10, 11, zob. niżej] znajdują się libelli strony pozwanej. Jak dotąd wszystkie wymienione wyżej elementy pozbawione były elementów chronologicznych. Dopiero pod koniec dokumentu przytoczona jest w całości treść wyroku audytora, wraz z formułą datacyjną: „Lecta, lata et in scriptis promulgata ...”. Na sentencji dokument może się kończyć, ale zwykle następuje jeszcze jedna część, informująca o oszacowaniu kosztów procesowych przez audytora. Wtedy data dokumentu odpowiada dacie taksacji kosztów. Oczywiście, oprócz wyżej przedstawionych pism z wyrokami, w razie potrzeby audytorzy mogli też wystawiać inne dokumenty, ale zwykle wiązały się one tylko z wybranym elementem procedury sądowej i przynoszą znacznie mniej informacji ${ }^{35}$.

W odróżnieniu od kancelarii papieskiej czy Kamery Apostolskiej, w Rocie nie prowadzono ksiąg, do których kopiowano by wystawiane przez audytorów dokumenty, także te zawierające wyroki. Jest to w pełni zrozumiałe, jeśli uwzględni się ich wyjątkowo dużą objętość. Jak wyżej pokazano, pisma te sporządzane były na podstawie materiałów procesowych przechowywanych przez notariuszy. Stosowny dokument można było wystawić nawet kilka lat po ogłoszeniu wyroku, jak stało się to w omawianym procesie ${ }^{36}$.

${ }^{30}$ Na przykład dokument z 16 II 1383 (zob. niżej) liczy ponad 33 tys. znaków; AP Wrocław, Rep. 66, nr 299 (298) [nr 9]; dokument Andrzeja Bareta z 10 V 1391 liczy ponad 37 tys. znaków; A. Salina, Polityka książat mazowieckich wobec władz Kościoła od początku XIV wieku do 1526 roku, Poznań 2011, s. 271-284.

31 Tak jest np. w przypadku omawianych niżej trzech dokumentów z 16 II 1383.

32 Podobny charakter mają w tym czasie również dokumenty oficjałów biskupich; zob. E. Knapek, Akta oficjalatu $i$ wikariatu generalnego krakowskiego do połowy XVI wieku, Kraków 2010, s. 118 n.

33 Sygnaturę papieską podawano zawsze w całości, gdyż określała ona dokładnie zakres zlecenia udzielonego audytorowi. Podanie treści sygnatury poprzedzała formuła: „In fine vero dicte commissionis sive supplicacionis cedule scripta erant de alterius manus littera, superiori littere ipsius commissionis penitus et omnino dissimili et diversa, hec verba ...”; AP Wrocław, Rep. 66, nr 299 (298) [nr 9], w. 11.

${ }^{34}$ Taka dodatkowa commissio jest np. w dokumencie z 23 VI 1378 (zob. niżej), gdzie klasztor poprosił o połączenie spraw o udzielenie absolucji z procesem o prawa do rzeki; AP Wrocław, Rep. 66, nr 272 [nr 3], w. 16-24.

35 Znamy kilka dokumentów audytorów (litterae compulsoriae) z wezwaniem do przedstawienia wszelkich materiałów związanych z sądzoną sprawą: ZDKK, t. 1, nr 113; KDWlkp., t. 9, nr 1111, 1143, 1184; KDWlkp., t. 10, nr 1632. Dokument audytora w innej sprawie: ZDKK, t. 1, nr 88.

${ }^{36}$ Zob. niżej, s. 49. 


\section{Zespól dokumentów dotyczących procesu Wernera von Czettritz z klasztorem św. Macieja}

Zanim przejdę do omawiania procesu i związanych z nim źródeł, dla łatwiejszego śledzenia toku dalszych rozważań, opartych na wielu dokumentach, warto najpierw wskazać, jak przedstawia się grupa owych dokumentów. W aneksie znajduje się ich chronologiczny wykaz, a w tekście artykułu w nawiasach kwadratowych podawane są ich kolejne numery. Po wyjątkowo dobrze udokumentowanym sporze majątkowym Czettritza z konwentem krzyżowców z Czerwoną Gwiazdą zachowało się aż 14 oryginalnych dokumentów, a uwzględniając znajdujące się w niektórych inserowane kopie, jest ich łącznie aż 18. Powstały one w poszczególnych etapach sporu toczącego się najpierw w kraju, a potem w Rocie. W procesie przed trybunałem papieskim można zaś wyróżnić fazę wstępną oraz proces posesoryjny i proces petytoryjny, przy czym po zakończeniu każdego z nich następowało postępowanie egzekucyjne. $Z$ procesem we Wrocławiu przed papieskim sędzią delegowanym Janem z Kunzendorfu łączą się 3 dokumenty (bulla Grzegorza XI [nr 1a], subdelegacja dla Kunzendorfa [nr 1b] i wyrok Kunzendorfa [nr 1]), z czego pierwsze dwa są kopiami inserowanymi w dokumencie z wyrokiem ${ }^{37}$. Z procesami w Rocie Rzymskiej bezpośrednio wiąże się 6 dokumentów wystawionych przez audytorów, a następnych 6 wytworzonych zostało podczas obu postępowań egzekucyjnych. Można więc powiedzieć, że w bezpośrednim związku z procesem w Rocie, uwzględniając też postępowanie egzekucyjne, powstało aż 12 obszernych dyplomów. Pierwszy z nich, we wstępnej fazie procesu, wystawił audytor Mikołaj z Cremony, udzielając konwentowi absolucji ad cautelam [nr 2] ${ }^{38}$. Następne dwa dotyczą procesu posesoryjnego (dokument z wyrokiem Mikołaja z Cremony [nr 3], taksacja kosztów procesowych [nr 5] $)^{39}$, a kolejne trzy są efektem postępowania egzekucyjnego (bulla egzekucyjna [nr 6], 2 dokumenty egzekutora Waltera Murnera $[\mathrm{nr} 7,8])^{40}$. Ponadto w czasie trwania procesu posesoryjnego kapituła zakonna zawarła umowę z mistrzem klasztoru św. Macieja, upoważniając go do działania przed sądem w imieniu klasztoru [nr 4$]^{41}$. Procesu petytoryjnego dotyczą 3 dokumenty z wyrokami w trzech kolejnych instancjach $[\mathrm{nr} 9,10,11]^{42}$, a z postępowaniem egzekucyjnym wiążą się 3 dokumenty: bulla egzekucyjna [nr 12] i dwa dokumenty egzekutora, opata Jana [nr 13, 14] ${ }^{43}$. W drugim z nich są inserowane dwa pisma Hermana von Czettritz [nr 14a, 14b] dotyczące jego zobowiązań w sprawie zapłaty długu za brata Wernera ${ }^{44}$. Przy okazji warto zauważyć, że nie licząc papieskich bulli i jednej obligacji Hermana von Czettritz, wszystkie dokumenty, czy to wystawiane w Rzymie, czy w kraju, mają formę instrumentu notarialnego z pieczęcią wystawcy ${ }^{45}$.

\section{Proces - przed sędzią delegowanym w kraju}

Sprawy własnościowe wnoszone przez Polaków przed trybunał Roty Rzymskiej zwykle toczyły się najpierw przez pewien czas w kraju, a do Stolicy Apostolskiej trafiały w drodze apelacji. Podobnie

\footnotetext{
37 AP Wrocław, Rep. 66, nr 257 (258), [nr 1] (zawiera dwa inserty [nr 1a, 1b]).

38 Tamże, nr 269 (269b) [nr 2].

39 Tamże, nr 272 [nr 3], 275 [nr 5].

${ }^{40}$ Tamże, nr 276 [nr 6], 277 [nr 7], 278 [nr 8].

${ }^{41}$ Tamże, nr 274 [nr 4].

42 Tamże, nr 297 (296) [nr 11], 298 (297) [nr 10], 299 (298) [nr 9].

43 Tamże, nr 300 (299) [nr 12], 301 (300) [nr 13], 304 (303) [nr 14].

44 Tamże, nr 304 (303) (zawiera dwa inserty [nr 14a, 14b]).

${ }^{45}$ Nie można więc zgodzić się z poglądem T. Jurka, że stosowanie instrumentu notarialnego uwierzytelnionego dodatkowo pieczęcią wystawcy było polską specyfiką („osobliwym zwyczajem”) i wyrazem zacofania; zob. tenże, Stanowisko dokumentu w średniowiecznej Polsce, St. Źródł., 40, 2002, s. 9. Rację należy przyznać M. Koczerskiej, polemizującej z tym stanowiskiem; zob. taż, Zbigniew Oleśnicki i Kościót krakowski w czasach jego pontyfikatu 1423-1455, Warszawa 2004, s. 140. Trzeba również zweryfikować twierdzenie K. Skupieńskiego, że instrumenty z pieczęcią były rzadkością na południe od Alp; por. tenże, Notariat publiczny w średniowiecznej Polsce, Lublin 1997, s. 137.
} 
było z rozważanym tutaj sporem. O początkach konfliktu kanonika Wernera von Czettritz ${ }^{46}$ z klasztorem św. Macieja we Wrocławiu ${ }^{47}$ i o przebiegu procesu sądowego w kraju informuje szczęśliwie zachowany dokument sędziego (subdelegata) Jana z Kunzendorfu z 19 VIII 1374 [nr 1], zawierający wydany przez niego we Wrocławiu wyrok ${ }^{48}$. W dokumencie tym przytoczone zostały w całości następujące dwa dokumenty: bulla papieża Grzegorza XI z 21 X 1372 [nr 1a] i dokument dziekana kolegiaty Świętego Krzyża Alberta von Schellendorf z subdelegacją dla Jana z Kunzendorfu (Wrocław, 22 IV 1373) [nr 1b], a także dwie skargi (libelli): skarga Wernera przeciwko trzem mieszkańcom Bierdzan i skarga wzajemna tychże przeciwko Wernerowi.

Jak informuje tekst skargi kanonika wrocławskiego Wernera von Czettritz, w 1370 r. otrzymał on in gratiam od biskupa Przecława z Pogorzeli folwark Księże Małe, należący do dóbr biskupich ${ }^{49}$. Posiadłość ta leżała pod Wrocławiem, na południowy wschód od miasta, na lewym brzegu niedużej rzeki Oławy, niedaleko jej ujścia do Odry ${ }^{50}$. Oława oddzielała folwark od wsi Bierdzany, stanowiącej własność klasztoru (szpitala) św. Macieja we Wrocławiu, zakonu krzyżowców z Czerwoną Gwiazdą. Według Wernera do posiadaczy folwarku należało też prawo do wyłącznego korzystania z rzeki Oławy (,possessores eiusdem predii in Czanscheyn [...] habuerunt [...] totam aquam seu decursum aque dicti fluvii Olavie") na całym odcinku granicznym z Bierdzanami ${ }^{51}$, a więc łowienia tam ryb, łapania ptaków i czerpania innych pożytków z rzeki. W korzystaniu z należnych praw, mimo wielokrotnych napomnień, przeszkadzali Wernerowi rybacy z Bierdzan: Staszek, włodarz w Bierdzanach, oraz Tammo i Jeszko z Bierdzan. Do konfliktu doszło w lutym 1371 r., gdy na zamarzniętej rzece niejaki Wawrzyniec, sługa kanonika Wernera, rozpiął sieci do chwytania ptactwa. Włodarz Staszek i jego dwaj towarzysze pochwycili Wawrzyńca, po czym zaciągnęli go do Wrocławia przed oblicze mistrza klasztoru, a przy okazji skonfiskowali mu sieci.

Czettritz zwrócił się więc ze skargą do Stolicy Apostolskiej i w odpowiedzi na jego prośbę papież Grzegorz XI bulla z 21 X 1372 [nr 1a] wyznaczył dziekana wrocławskiej kolegiaty Świętego Krzyża na sędziego delegowanego, któremu powierzył rozsądzenie sporu ${ }^{52}$. Ówczesny dziekan, Albert von Schellendorf ${ }^{53}$, dokumentem wystawionym we Wrocławiu 22 IV 1373 [nr 1a] udzielił subdelegacji Janowi z Kunzendorfu, kanonikowi lubuskiemu i wikariuszowi katedry wrocławskiej, który wkrótce wezwał strony przed swój sąd. W przywoływanej wyżej skardze Werner von Czettritz oszacował poniesione straty na 50 grzywien i zwrócił się do sędziego, by ten orzekł, iż na spornym odcinku rzeka Oława wraz ze wszystkimi prawami należy do folwarku Księże Małe oraz by skazał stronę pozwaną na zapłacenie 50 grzywien dla pokrycia wyrządzonych szkód. Charakterystyczne jest, że w swojej skardze kanonik kilkakrotnie podkreśla, iż sporne prawa należą do niego, jako obecnego użytkownika majątku,

${ }^{46}$ Kanonik Werner von Czettritz pochodził z liczącego się na Śląsku rodu szlacheckiego. Był plebanem w Jaworze, a później kanonikiem wrocławskim, w suplice określony mianem kapelana cesarskiego; G. Schindler, Das Breslauer Domkapitel von 1341-1417. Untersuchungen über seine Verfassungsgeschichte und persönliche Zusammensetzung, Breslau 1938, s. $202 \mathrm{n}$. O tej gałęzi rodu Czettritzów zob. B. Ludwig, Fundacje sakralne Czettritzów w Wałbrzychu i okolicach, Wrocław 2014, s. 15-19; zob. też T. Jurek, Obce rycerstwo na Śląsku do połowy XIV wieku, Poznań 1996 (indeks: Zettritz); M.L. Wójcik, Pieczęcie rycerstwa śląskiego w dobie przedhusyckiej, t. 2, Kraków-Wrocław 2018, s. 889 n. (tam bibliografia).

47 Obecnie w budynkach wrocławskiego klasztoru św. Macieja, zakonu krzyżowców z Czerwoną Gwiazdą, ma swoją siedzibę Zakład Narodowy im. Ossolińskich.

48 AP Wrocław, Rep. 66, nr 257 (258) [nr 1].

${ }^{49}$ Nadawanie dóbr stołowych kanonikom było stałą praktyką; K. Dola, Wrocławska kapituła katedralna w XV wieku, Lublin 1983, s. 64. Folwark Księże Małe był nadawany in gratiam już w XIII w.; por. Liber fundationis episcopatus Vratislaviensis, wyd. H. Markgraf, J.W. Schulte, CDSil., t. 14, Breslau 1889, s. 49: „Hec sunt ville et allodia canonicorum de mensa domini episcopi” (folwark ten występuje pod nazwą „Zassino”).

${ }^{50}$ Dzisiaj jest to osiedle Księże Małe, w granicach Wrocławia.

${ }^{51}$ W skardze dokładnie opisano należący do folwarku odcinek rzeki, podając, że rozciągał się on od dębu od strony wsi Świątniki, aż po młyn na Oławie.

52 Bulla ta nie zachowała się w papieskich registrach kancelaryjnych, ale w całości została przytoczona w dokumencie Jana z Kunzendorfu z 19 VIII 1374; AP Wrocław, Rep. 66, nr 257 (258) [nr 1], w. 5-8.

${ }^{53}$ Niewielki biogram Alberta w: C. Kuchendorf, Das Breslauer Kreuzstift in seiner persönlichen Zusammensetzung von der Gründung (1288) bis 1456, Breslau 1937, s. 125. 
ale i do katedry wrocławskiej, a uzurpacja rybaków z Bierdzan narusza prawa katedry i przysługujące jej wolności kościelne.

W złożonej przez pozwanych skardze wzajemnej, która również została przytoczona w całości, włodarz Staszek i jego dwaj kompani oświadczyli, że wyłączne prawo do czerpania pożytków z rzeki Oławy należy do szpitala św. Macieja, oni zaś wydzierżawili je od klasztoru za 7 grzywien groszy praskich rocznie i obecnie sa jedynymi uprawnionymi do korzystania $\mathrm{z}$ tego prawa. Swoje straty, spowodowane działalnością Wernera von Czettritz, oszacowali na aż 60 grzywien groszy praskich. Prokurator pozwanych zwrócił się do sędziego o zawyrokowanie, że prawo do korzystania z Oławy przysługuje wyłącznie klasztorowi oraz o skazanie Wernera na zapłacenie 60 grzywien na rzecz pokrzywdzonych dzierżawców. Ostatecznie, wyrokiem wydanym we Wrocławiu 19 VIII 1374 [nr 1], Jan z Kunzendorfu oddalił wzajemne roszczenia Wernera von Czettritz i trzech pozwanych z Bierdzan, kończąc w ten sposób spór sądowy pomiędzy nimi ${ }^{54}$.

Kolejne szczegóły pierwszej fazy procesu o prawa do rzeki Oławy dodaje pismo procesowe (libellus sive petitio summaria) Wernera von Czettritz złożone niemal trzy i pół roku później (13 I 1378) w Rocie Rzymskiej, zacytowane w całości w dokumencie audytora Mikołaja z Cremony z wyrokiem w procesie posesoryjnym z 23 VI 1378 [nr 1a] (o czym niżej) ${ }^{55}$. Choć jak zwykle w treści libellusa nie podano jego daty, to dzięki szczególnej sytuacji znamy moment jego złożenia. Przez pewien bowiem czas równocześnie z procesem posesoryjnym toczył się też proces petytoryjny i w swoim wyroku audytor wyraźnie zaznaczył, że orzeczenie odnosi się do pisma z 13 I 1378 przedłożonego w procesie posesoryjnym, a nie do libellusa $\mathrm{w}$ procesie petytoryjnym z 7 maja tegoż roku ${ }^{56}$. Większość podanych tam informacji dokładnie pokrywa się z tymi znanymi ze skargi w postępowaniu przed Janem z Kunzendorfu sprzed kilku lat. Niekiedy wręcz użyte są niemal identyczne sformułowania, jak np. przy opisie granic folwarku Księże Małe. Można jednak zauważyć również istotne różnice. Oprócz napaści na familiarisa Wawrzyńca w lutym 1371 r., kanonik Werner dodał, że ponowna napaść na jego sługę przez tych samych trzech mieszkańców Bierdzan miała miejsce w marcu 1373 r. Włodarz Staszek i jego dwaj towarzysze pochwycili tym razem niejakiego Mikołaja, zabrali mu sieci oraz złowione ryby i od tej pory, na polecenie konwentu św. Macieja, uniemożliwiali rybakom z folwarku korzystanie z przynależnych im - według Wernera - praw do połowów w Oławie. Co ciekawe, wcześniej, w procesie przed Janem z Kunzendorfu, który rozpoczął się po 22 IV 1373 ${ }^{57}$, Czettritz nie wspomniał o tej ponownej napaści. Być może zawierało się to w ogólnym stwierdzeniu o przeszkodach czynionych mu przez klasztor. Swoje straty, tak samo jak kilka lat wcześniej, Werner oszacował na 50 grzywien. W libellusie przedłożonym w Rocie nie ma też informacji, że włodarz Staszko oraz Tammo i Jeszko wydzierżawili prawo do połowu ryb w Oławie od krzyżowców z Czerwoną Gwiazdą. Czytając dokument z 1378 r., można odnieść wrażenie, że cała trójka to ludzie (słudzy) klasztoru, a skarga z 1373 r. (w dok. nr 1) jest jedynym miejscem, gdzie wskazano, iż w rzeczywistości byli oni dzierżawcami.

Wyrok z 1374 r., w którym Jan z Kunzendorfu oddalił wzajemne roszczenia Wernera von Czettritz i trzech rybaków z Bierdzan, nie oznaczał oczywiście, że między stronami nie było konfliktu. Po prostu w sposób typowy dla dokumentów sądowych ograniczono się tylko do podania sentencji, bez jakiegokolwiek jej uzasadnienia. Suplika złożona przez konwent krzyżowców przy okazji apelacji do Roty Rzymskiej wyjaśnia, co naprawdę oznaczał ten wyrok $^{58}$. Według supliki pozwani przez kanonika Wernera trzej mieszkańcy Bierdzan oświadczyli, że działają w imieniu klasztoru (niewątpliwie dlatego, że są tylko dzierżawcami) oraz wskazali na zakonników jako swoich panów i właściwych adresatów pozwu. W tej sytuacji Jan z Kunzendorfu zdecydował się wezwać przed swój sąd konwent św. Macieja, co wkrótce doprowadziło do przeniesienia sporu przed papieski trybunał. Zakonnicy zanegowali bowiem

${ }^{54}$ AP Wrocław, Rep. 66, nr 257 (258) [nr 1], w. 36-46.

55 Tamże, nr 272 [nr 3], w. 29-52.

56 Tamże, w. 77 n.

57 Dopiero tego dnia Jan z Kunzendorfu otrzymał delegację od dziekana Alberta von Schellindorf.

${ }^{58}$ Suplika ta jest podana w całości w dokumentach; AP Wrocław, Rep. 66, nr 269 (269b) [nr 2], nr 272 [nr 3] (tu jest zrelacjonowana, w mowie zależnej), nr 299 (298) [nr 9]. 
możliwość takiego rozszerzenia delegacji przez sędziego Jana, która wyraźnie pozwalała mu tylko na osądzenie sprawy przeciwko włodarzowi Staszkowi oraz Tammonowi i Jeszkowi z Bierdzan. Wskazano zwłaszcza na fakt, że nie tylko nie wolno dowolnie zmieniać zakresu delegacji, ale zwłaszcza odnosi się to do rozciągnięcia jej na osoby stojące wyżej niż pozwani rybacy.

Sędzia Jan z Kunzendorfu nie uznał argumentacji wrocławskiego konwentu i dalej procedował. W suplice klasztoru wskazano, że opinie prawników w kwestii zakresu delegacji były podzielone („,de hinc diverse sunt in partibus interlocutorie, eciam contrarie, prolate" $)^{59}$. Zakonnicy uznali, że z powodu braku we Wrocławiu wystarczająco dobrych prawników („propter iurisperitorum defectum”) nie uzyskają w kraju sprawiedliwego wyroku i zdecydowali się apelować do Stolicy Apostolskiej. Wiele wskazuje na to, że prawdziwym powodem apelacji nie były jednak zastrzeżenia co do poziomu wiedzy miejscowych prawników, ale był to czysto formalny pretekst, by przenieść proces do Roty (zob. niżej). Niewątpliwie taka zmiana sądu spowodować musiała poważny wzrost kosztów procesowych dla obu stron i znaczne wydłużenie postępowania, ale stawiała konwent w korzystniejszej sytuacji. Bogaty klasztor św. Macieja z pewnością dysponował większymi środkami niż pojedynczy kanonik.

Pomimo złożonej do Stolicy Apostolskiej apelacji, co automatycznie powinno doprowadzić do zawieszenia procesu w kraju, sędzia Jan dalej kierował wezwania do krzyżowców i w końcu nałożył na nich ekskomunikę, którą publicznie ogłoszono. Nie wiadomo dokładnie, co było bezpośrednią przyczyną nałożenia cenzury, bo omawiana suplika o tym nie mówi ${ }^{60}$. Złożone w późniejszym czasie pismo procesowe (petitio) wspomina, że owa kara kościelna została nałożona na zakonników z powodu niezapłacenia Czettritzowi sumy 5 kóp groszy praskich ${ }^{61}$. Była to kwota wydatków, jakie poniósł Werner w sporze z krzyżowcami, co oznacza, że sędzia ogłosił kanonika zwycięzcą w procesie i zaocznie skazał przegranych na zapłacenie kosztów sądowych. Gdy zakonnicy uznali, że po złożeniu apelacji działania Kuntzendorfa nie mają podstaw prawnych, nie zaakceptowali wydanego wyroku ani nie zapłacili zasądzonej kwoty.

\section{Proces - przed trybunalem Roty}

\section{a) faza wstępna}

Apelacja do Stolicy Apostolskiej, która w tym czasie znajdowała się jeszcze w Awinionie, spowodowała rozpoczęcie procesu w Rocie. Jego rozstrzygnięcie papież powierzył audytorowi Mikołajowi z Cremony ${ }^{62}$. Na żądanie Jana Goswinowica ${ }^{63}$, prokuratora konwentu, audytor pozwał przed swój sąd Jana z Kunzendorfu oraz kanonika Wernera von Czettritz i rozpoczęła się normalna procedura. Załatwienia wymagała najpierw sprawa cenzur, które wrocławski sędzia nałożył na stronę klasztorną. Choć konwent nie uznał prawomocności kary kościelnej, to jednak została ona publicznie ogłoszona, zakonnicy zwrócili się więc do papieża o udzielenie im absolucji ad cautelam $^{64}$. Sprawa została odesłana również do Mikołaja z Cremony, który zajmował się już apelacją krzyżowców. Na pewne wydłużenie postępowania

59 Tamże, nr 299 (298) [nr 9], w. 7; podobnie nr 272 [nr 3], w. 6.

${ }^{60} \mathrm{Z}$ tekstu supliki przedłożonej papieżowi można odnieść wrażenie, jakby powodem nałożenia ekskomuniki było niestawiennictwo zakonników w sądzie, po tym, jak strona klasztorna złożyła apelację do Stolicy Apostolskiej. To oznacza jednak, że apelacja musiałaby zostać złożona dużo wcześniej niż suplika, w której sprawę opisano. Raczej zatem w suplice zastosowano pewien skrót myślowy, a powód ekskomuniki był inny.

${ }^{61}$ AP Wrocław, Rep. 66, nr 269 (269b) [nr 2], w. 53-65.

${ }^{62}$ Niccolò Zanasio di Cremona, bp Brescii (1378-1384), bp Beneventu (1384-1385), abp Neapolu (1385-1389); zob. C. Eubel, Hierarchia catholica medii aevi, t. 1, Monasterii 1913, s. 133, 147, 360; <http://www.castelbolognese.org/biografie-personaggi/personaggi/niccolo-zanasio-1389/> [dostęp: 10.04.2020]. Audytora tego wskazano w commissio (suplika-zlecenie), które rozpoczęło proces; zob. wyżej, przyp. 21.

${ }^{63}$ Jan Goswinowic, dr dekretów, kanonik wrocławski i poznański; H. Gerlic, Kapituła głogowska w dobie piastowskiej i jagiellońskiej (1120-1526), Gliwice 1993, s. 237.

${ }^{64} \mathrm{~W}$ tym przypadku była to absolucja udzielana tylko w odniesieniu do spraw wiążących się z toczonym aktualnie procesem, bez rozstrzygania, czy została słusznie nałożona; por. Encyklopedja Kościelna podtug teologicznej encyklopedji Wetzera $i$ Weltego, t. 3, red. x. M. Nowodworski, Warszawa 1874, s. 190 (hasło: Cenzury kościelne). 
musiało niewątpliwie wpłynąć przeniesienie Kurii Rzymskiej do Wiecznego Miasta. Papież Grzegorz XI wyjechał z Awinionu we wrześniu 1376 r. i 17 stycznia następnego roku powrócił do Rzymu. Ostatecznie dokumentem wystawionym w Rzymie 4 III 1377 [nr 2] papieski audytor ogłosił zniesienie cenzur nałożonych przez Jana z Kunzendorfu, udzielając zakonnikom absolutionis ad cautelam ${ }^{65}$. To właśnie w tym dokumencie zostały przytoczone wspomniane wyżej dwie supliki (commissiones) i petitio strony klasztornej, w których proszono o rozpatrzenie sporu przez sędziego papieskiego oraz o udzielenie absolucji. Kunzendorf i Czettritz próbowali jeszcze na drodze proceduralnej powstrzymać proces w Rocie i dwukrotnie odwoływali się od wyroku Mikołaja z Cremony, ale audytorzy Idzi Bellemere $^{66}$ i Franciszek Lando ${ }^{67}$ kolejno zatwierdzili orzeczenie audytora Mikołaja w sprawie absolucji ${ }^{68}$. Proces sądowy mógł więc wreszcie ruszyć.

\section{b) proces posesoryjny}

Jak już wspomniano, omawiany spór sądowy jest szczególnie interesujący nie tylko dlatego, że jest wyjątkowo dobrze udokumentowany, ale także ze względu na jego znaczne rozbudowanie i skomplikowanie pod względem proceduralnym. Najpierw, około początku 1378 r. ruszył tzw. proces posesoryjny. Postępowanie posesoryjne, mające swój początek w prawie rzymskim, zostało na trwałe wprowadzone do prawa europejskiego w średniowieczu, najpierw w prawie kanonicznym, a pod jego wpływem u schyłku wieków średnich przejęte zostało przez prawa świeckie. Celem procesu posesoryjnego było przywrócenie posiadania ${ }^{69}$ rzeczy osobie, która została go bezprawnie (bez wyroku sądu) pozbawiona, w myśl zasady: spoliatus ante omnia restituendus (,wyzutego z posiadania należy przede wszystkim do posiadania przywrócić"). Chodziło więc tylko o tymczasowe przywrócenie stanu sprzed wybuchu sporu, bez rozsądzania, która ze stron sporu ma rzeczywiste prawo do rzeczy (ius in re). Tym ostatnim zajmował się już proces petytoryjny. Proces posesoryjny był postępowaniem sumarycznym (skróconym), a przez to również szybszym i tańszym niż petytoryjny ${ }^{70}$.

Informacji o przebiegu postępowania posesoryjnego dostarcza dokument audytora Mikołaja z Cremony z 23 VI 1378 [nr 3]. Jest to typowy dokument, w którym opisano przebieg procesu i podano wyrok audytora. W omawianej już wyżej pierwszej commissio przedstawiono początek sporu miedzy zwaśnionymi stronami, a ponadto przytoczono w całości kolejne akta: późniejszą suplikę (commissio) strony klasztornej o rozpatrzenie wraz z apelacją także sprawy głównej, czyli sporu o prawo do korzystania z rzeki ${ }^{71}$, obszerne pismo procesowe (libellus seu peticio summaria) Wernera von Czettritz z 13 I 1378 i oczywiście wyrok audytora z 23 czerwca. Na to, że chodzi o postępowanie posesoryjne, wskazuje wielokrotne użycie słowa possessio w piśmie procesowym i prośba kanonika, by sąd papieski przywrócił go do posiadania $^{72}$, kilkakrotne użycie słowa possessio w opisie kolejnych kroków proceduralnych, a wreszcie stwierdzenie w samym wyroku, że jest on wydany ,in causa dumtaxat possessorii”’33. Ponadto na stronie dorsalnej dokumentu ręka z XV w. napisała: „Czwpernyk ${ }^{74}$, sentencia in possessorio lata”. Oprócz wskazanych już wcześniej różnic między treścią libellusa z 13 I 1378 a informacjami znanymi ze skargi

${ }^{65}$ AP Wrocław, Rep. 66, nr 269 (269b) [nr 2] (4 III 1377).

${ }_{66}$ Zob. H. Gilles, La vie et les oeuvres de Gilles Bellemère, „Bibliothèque de l'École des Chartes”, 124, 1966, s. $30-136$.

${ }^{67}$ Zob. D. Girgensohn, Lando Francesco, w: Dizionario Biografico degli Italiani, t. 63, Roma 2004, <https://www.treccani. it/enciclopedia/francesco-lando_(Dizionario-Biografico)/> [dostęp: 10.04.2020].

${ }^{68}$ AP Wrocław, Rep. 66, nr 272 (23 VI 1378) [nr 3], w. 20 n.

69 Przez posiadanie (possessio) rozumie się faktyczne władztwo nad rzeczą, w odróżnieniu od własności. Posiadaczem rzeczy może być zarówno jej właściciel, jak i dzierżawca czy użytkownik.

${ }^{70}$ W. Uruszczak, Spoliatus ante omnia restituendus. Znaczenie prawa kanonicznego w rozwoju ochrony posiadania, w: Possessio ac iura in re. Z dziejów prawa rzeczowego, red. M. Mikuła, W. Pęksa, K. Stolarski, Kraków 2012, s. 17-24.

${ }^{71}$ AP Wrocław, Rep. 66, nr 272 [nr 3], w. 16-24. To właśnie w tej suplice jest informacja o dwukrotnej apelacji kanonika Wernera i sędziego Jana z Kunzendorfu od udzielonej konwentowi absolucji ad cautelam.

72 Tamże, w. 47.

73 Tamże, w. 77.

${ }^{74}$ Inna nazwa folwarku Księże Małe. Klasztorny archiwista z przełomu XIV i XV w. wpisał nazwę „Czupernik” na stronach dorsalnych niemal wszystkich dokumentów związanych z procesem. 
złożonej w procesie we Wrocławiu warto jeszcze zauważyć, że w piśmie złożonym w Rocie brak jest wzmianek o naruszaniu praw katedry wrocławskiej przez przeciwników Czettritza, co tak mocno było podkreślane we wcześniejszej skardze. Cały czas jest mowa wyłącznie o prawach kanonika Wernera.

Szczególnie istotna była wspomniana commissio, w całości zacytowana w dokumencie, w której papież - na prośbę klasztoru - nakazał połączenie ze sobą sprawy apelacji od rozszerzenia zakresu delegacji przez Jana z Kunzendorfu i sprawy głównej, czyli sporu o prawo własności. Według zakonników fakt, iż sprawa o własność nie została wspomniana już w pierwszej commissio, spowodowany był „nieuwagą pisarza”, co jest zresztą typowym zwrotem formularzowym w papieskich suplikach ${ }^{75}$. W rzeczywistości powód był inny. Bulla Grzegorza XI z 1372 r. [nr 1a], nakazująca rozsądzenie sprawy sędziemu delegowanemu, zakazywała apelacji od jego wyroku ${ }^{76}$. Klasztor złożył więc najpierw apelację tylko od niewłaściwego rozszerzenia delegacji przez Kunzendorfa, a dopiero potem do trwającego w Rocie postępowania dołączył sprawę główną. W ten sposób ominięty został zakaz apelacji i krzyżowcom udało się ostatecznie przenieść cały spór przed papieski trybunał.

Wyrok (sententia diffinitiva) audytora został wydany 23 VI 1378. Papieski sędzia orzekł na korzyść klasztoru wrocławskich krzyżowców z Czerwoną Gwiazdą, przyznając im posiadanie spornego prawa do czerpania pożytków z rzeki oraz skazał Wernera na zapłacenie kosztów sądowych w procesie posesoryjnym i zarezerwował sobie prawo oszacowania tych kosztów w późniejszym czasie. Ponadto zastrzegł dla siebie władzę osądzenia sprawy w procesie petytoryjnym ${ }^{77}$. Czettritz nie skorzystał z prawa do apelacji, proces posesoryjny zakończył się więc na I instancji.

Wprawdzie w dokumencie z wyrokiem znajdują się głównie informacje o charakterze proceduralnym, ale pozwalają one dostrzec pewne cechy toczącego się procesu. Warto zauważyć, że w apelacji od nałożonej przez Jana z Kunzendorfu ekskomuniki oraz na początku procesu posesoryjnego mowa jest o wezwaniu przez audytora przed sąd Roty zarówno sędziego subdelegowanego Jana z Kunzendorfu, jak i kanonika Wernera, a prokuratorzy zawsze określani są jako reprezentanci ich obu. Natomiast po złożeniu przez klasztor supliki o łączne rozpatrzenie wraz z apelacją także sprawy głównej (negocium principale), czyli sporu o własność prawa do korzystania z rzeki, zawsze już pojawia się prokurator działający wyłącznie w imieniu Wernera von Czettritz, także w dalszych etapach procesu. Pojawiły się też problemy z udziałem pełnomocnika Czettritza w posiedzeniach sądu. Prokurator Mikołaj z Wołowa ${ }^{78}$ kilka razy nie pojawił się $\mathrm{w}$ wyznaczonym terminie, został uznany za uporczywie niestawiającego się (contumax) i w konsekwencji proces toczył się zaocznie, co stawiało Wernera w niekorzystnej sytuacji. Natomiast mistrz Jan Goswinowic, pełnomocnik strony klasztornej, a najczęściej jego substytut Giso Katzmann z Fritzlaru ${ }^{79}$, był obecny na każdej rozprawie.

Zanim zakończony został proces posesoryjny przed Mikołajem z Cremony, kapituła śląskich i kujawskich klasztorów krzyżowców z Czerwoną Gwiazdą podjęła ciekawą decyzję, związaną z toczącym

75 „Verum Pater Sancte in primeva commissione per inadvertenciam et ut presumitur scriptoris negligenciam fuit negocium principale obmissum, quod vertitur inter dictas partes de et super quibusdam piscinis seu piscariis, iniuriis, dampnis et rebus aliis, quare Pater Sancte supplicatur e[iusdem] S[anctitati] V[estre] pro parte dicti preceptoris et conventus, quatenus ut partibus laboribus et expensis parcetur et ne causarum continencie dividantur committere dignemini supradicto domino Nicolao de Cremona [...] dictum negocium principale cum suis emergentibus [...] eciam cum causa appellacionis predicte audiendum, decidendum et fine debito terminandum"; AP Wrocław, Rep. 66, nr 272 [nr 3], w. 21-23.

76 Polecenie papieskie skierowane do sędziego brzmiało: „mandamus, quatenus partibus convocatis audias causam et appellacione remota [podkr. M.D.K.] debito fine decidas, faciens quod decreveris per censuram ecclesiasticam firmiter observari"; tamże, nr 257 (258) [nr 1a], w. 6 n.

77 Tamże, nr 272 [nr 3], w. 78.

78 Ślązak, familiaris papieski, posiadacz wielu beneficjów, w tym kanonii wrocławskiej; G. Schindler, Das Breslauer Domkapitel, s. $391 \mathrm{n}$.

${ }^{79}$ Giso Katzmann z Fritzlaru (zm. 1404), scholastyk we Fritzlarze; zob. biogram w: K.E. Demandt, Das Chorherrenstift St. Peter zu Fritzlar. Quellen und Studien zu seiner mittelalterlichen Gestalt und Geschichte, Marburg 1985, s. 588, nr 201. Przez krótki czas zakonników reprezentował też Jan Libezeit, wikariusz wieczysty w kolegiacie Grobu Bożego w Legnicy i jego substytut mistrz Bartolino z Piacenzy; AP Wrocław, Rep. 66, nr 269 (269b) [nr 2] (4 III 1377); S. Jujeczka, Duchowni średniowiecznej Legnicy. Studium prozopograficzne nad klerem diecezjalnym, Legnica 2006, s. 294 n., nr 260. 
się sporem sądowym. Zgromadzeni na kapitule prowincjalnej ${ }^{80}$ zakonnicy oddali dożywotnio swojemu mistrzowi Janowi Sebinwirt ${ }^{81}$ prawo połowu ryb i czynsz w wysokości 7 grzywien groszy praskich z Bierdzan, wraz z innymi dochodami z tych dóbr (np. prawem pozyskiwania drewna z lasu zakonnego), a w zamian mistrz Jan wziął na siebie trud i koszty prowadzenia sporu przeciwko Wernerowi von Czettritz ${ }^{82}$. Umowę z Sebinwirtem potwierdzono dokumentem z 7 X 1378 [nr 4]. Stwierdzono w nim, że kanonik Werner zajął tzw. rybnik na rzece Oławie i wytoczył klasztorowi św. Macieja sprawę w sądzie, a na trwający proces wydano dotychczas duże sumy pieniędzy ${ }^{83}$. Trudno dokładnie wyjaśnić, dlaczego kapituła zdecydowała się na taki krok. Być może chodziło o to, by mistrz Jan mógł samodzielnie podejmować decyzje w związku z toczącym się postępowaniem w Rocie, bez ubiegania się co chwila o zgodę wspólnoty zakonnej.

Kolejnym krokiem po wydaniu wyroku przez audytora było określenie kosztów sądowych, które przegrany musiał zapłacić zwycięskiej stronie. W tym celu Mikołaj z Cremony wezwał pełnomocników obu stron, ale kolejny raz na rozprawie stawił się tylko Giso Katzmann, natomiast Branchino Besozzi z Mediolanu ${ }^{84}$, prokurator Wernera, nie pojawił się w sądzie. W tej sytuacji audytor uznał Branchina winnym niestawiennictwa i zaocznie ustalił wysokość kosztów procesowych na 40 florenów. Podstawą do oszacowania było - jak zawsze - poparte przysięgą oświadczenie Gisona, że strona klasztorna poniosła wydatki w takiej właśnie wysokości ${ }^{85}$. Określenie wysokości kosztów sądowych miało miejsce dopiero 23 III 1379, a więc aż dziewięć miesięcy po wydaniu wyroku, co potwierdził swoim dokumentem Mikołaj z Cremony [nr 5] $]^{86}$. Dokument taksacji określany jest w źródłach, np. w subskrypcji notarialnej lub w papieskiej bulli, jako instrumentum condempnacionis et taxacionis. Podobnie jak dyplom z wyrokiem, miał formę instrumentu notarialnego opatrzonego pieczęcią audytora.

\section{c) postępowanie egzekucyjne po procesie posesoryjnym}

Otaksowanie kosztów zamykało postępowanie (lub pewien jego etap) toczone przed audytorem Roty Rzymskiej, ale nie oznaczało końca starań związanych ze sporem. Kolejnym stadium było postępowanie egzekucyjne. Najpierw zwycięska strona musiała uzyskać papieską bullę egzekucyjną. Na suplikę zakonników papież Urban VI dokumentem z 11 IV 1379 [nr 6] nakazał trzem wskazanym egzekutorom, by mocą władzy apostolskiej (czyli w imieniu papieża) ogłosili wydany przez audytora wyrok i nakazali Wernerowi von Czettritz zapłacenie na rzecz klasztoru św. Macieja zasądzonych 40 florenów kosztów procesowych. Na egzekutorów wyznaczeni zostali (niewymienieni z imienia): prepozyt w Brixen, prepozyt szpitala Świętego Ducha we Wrocławiu i dziekan kolegiaty Świętego Krzyża we Wrocławiu ${ }^{87}$.

${ }^{80} \mathrm{~W}$ sensie formalnym nie można mówić o prowincji śląsko-kujawskiej krzyżowców z Czerwoną Gwiazdą, ale ta gałąź zakonu miała pewną odrębność, w tym swojego mistrza (magister seu praeceptor) i kapitułę generalną, na którą zjeżdżali się przełożeni domów z terenów Śląska i Kujaw; zob. M. Starnawska, Między Jerozolima a Łukowem. Zakony krzyżowe na ziemiach polskich w średniowieczu, Warszawa 1999, s. 125-127.

81 Jan Sebinwirt (Zebinwirt) był mistrzem krzyżowców z Czerwoną Gwiazdą w latach 1370-1391, według zapiski w nekrologu, sporządzonym w XVIII w. na podstawie dawniejszych przekazów, zmarł 26 II 1391; Národní archiv Praha, fond Kř́̌žovníci s červenou hvězdou - generalát a konvent, Praha, kniha 231, „Calendarium mortuorum Sacri ac Militaris Ordinis Crucigerorum cum Rubea Stella [...] compositum a P. Antonio Tudetius [...] anno 1743” (zapiska udostępniona przez dr. Stanisława Jujeczkę z Uniwersytetu Wrocławskiego, któremu składam wyrazy podziękowania); zob. też Series et acta magistrorum Wratislaviensium sacri militaris ordinis crucigerorum cum rubea stella hospitalis sancti Mathiae [...] a [...] Michaele Josepho Fibiger [...] conscripta, w: Scriptores rerum Silesiacarum oder Sammlung Schlesischer Geschichtsschreiber, t. 2, wyd. G.A. Stenzel, Breslau 1839, s. 305.

${ }^{82}$ Przy okazji umowa ta jest jednym z najstarszych świadectw posiadania przez zakonników odrębnych, prywatnych dochodów.

${ }^{83}$ AP Wrocław, Rep. 66, nr 274 [nr 4].

${ }^{84}$ Branchino Besozzi di Milano, późniejszy bp Bergamo (1381-1399); P. Supino, Besozzi Branchino, w: Dizionario Biografico degli Italiani, t. 9, Roma 1967, <https://www.treccani.it/enciclopedia/branchino-besozzi_(Dizionario-Biografico)> [dostęp: 10.04.2020]; C. Eubel, Hierarchia catholica, t. 1, s. 396.

${ }^{85} \mathrm{Na}$ temat ustalania wysokości kosztów sądowych, choć w późniejszym czasie, zob. Ch. Bukowska-Gorgoni, Causae Polonae, s. $41 \mathrm{n}$.

${ }^{86}$ AP Wrocław, Rep. 66, nr 275 [nr 5].

87 Tamże, nr 276 [nr 6]. 
Warto w tym miejscu zauważyć, że zwycięska strona mogła zwrócić się o bullę egzekucyjną jeszcze przed otaksowaniem kosztów procesowych. W takiej sytuacji papież nakazywał wprowadzić w życie tylko sam wyrok audytora ${ }^{88}$. Z oczywistych względów najczęściej jednak spotykamy się z sytuacją, gdy bulla powstawała już po określeniu należnej zapłaty od przegranego. W przeciwieństwie do dokumentów wystawionych przez audytorów, których przetrwało do dziś stosunkowo niewiele, bulle egzekucyjne zachowały się w znacznie większej liczbie. Wprawdzie oryginałów jest również niewiele, ale dysponujemy pokaźną liczbą urzędowych kopii z registrów papieskiej kancelarii. To właśnie bulle egzekucyjne są więc najczęstszym przekazem dotyczącym procesów toczonych w Rocie Rzymskiej w okresie, z którego nie zachowało się archiwum tego trybunału, i z dokumentami tego typu historycy mają okazję spotykać się najczęściej. Z tego względu warto przyjrzeć się bliżej bulli egzekucyjnej [nr 6] i porównać ją z dokumentem z 23 VI 1378, zawierającym wyrok audytora [nr 3].

Tekst bulli egzekucyjnej jest niemal czterokrotnie krótszy niż tekst dokumentu audytora ${ }^{89}$. Pominięto w niej całkowicie informacje na temat początkowych stadiów procesu, i to zarówno tych toczących się w kraju, jak i w Rocie Rzymskiej. Ograniczono się tylko do podania, że między wrocławskim klasztorem św. Macieja a Wernerem von Czettritz wybuchł spór sądowy o prawo do korzystania z rzeki Oławy koło folwarku Księże Małe, a papież Grzegorz XI powierzył sprawę audytorowi Mikołajowi z Cremony. Z obszernego i pełnego szczegółów libellusa kanonika Wernera podano tylko jego prośbę, by papieski sędzia przywrócił go do posiadania spornej rzeczy, by uznał, że przysługuje mu prawo do korzystania z rzeki Oławy oraz by klasztor zapłacił mu 50 grzywien odszkodowania za poniesione straty. W bulli nie pojawiają się żadne wzmianki o wydarzeniach, które doprowadziły do sporu sądowego, nie wspomniano o postępowaniu we Wrocławiu przed papieskim sędzią delegowanym, nie pojawia się nazwisko sędziego-subdelegata Jana z Kunzendorfu, pozywanego wszak wraz z Wernerem przez klasztor, ani prokuratorów obu stron, występujących we wcześniejszej fazie procesu w Rocie: Branchina Besozziego z Mediolanu, Jana Libezeita i Bartolina z Piacenzy. Nie ma też wzmianki o udzielonej konwentowi absolucji ad cautelam ani - co zrozumiałe - szczegółowego opisu granic folwarku. W dalszej części bulli przedstawiono przebieg procesu w Rocie. Wymieniono wszystkie etapy formalne, które są opisane $\mathrm{w}$ dokumencie audytora, przekazując w zasadzie niemal ten sam zasób informacji w tekście o trzykrotnie mniejszej długości. Tak znaczna redukcja możliwa była dzięki pominięciu formularzowego pustosłowia. Wyrok audytora Mikołaja z Cremony przekazano w zwięzłej formie, zaznaczając wyraźnie, że konwent krzyżowców został uwolniony od roszczeń kanonika Wernera „quoad possessorium dumtaxat”90, a następnie podano informację o otaksowaniu kosztów procesowych przez audytora na 40 florenów, po czym powołano się na oba dokumenty audytora: ,prout in instrumentis publicis inde confectis dicti auditoris sigillo munitis dicitur plenius contineri" ${ }^{\prime 1}$. Bullę zamyka krótka dyspozycja, w której papież nakazuje egzekutorom, by ogłosili wyrok i nakazali Wernerowi zapłacenie kosztów procesowych.

Wkrótce po otrzymaniu bulli egzekucyjnej brat Franciszek Molendinatoris, zakonnik z konwentu św. Macieja, przebywający w Rzymie jako pełnomocnik strony klasztornej, udał się do jednego z egzekutorów wskazanych w bulli papieskiej po stosowny dokument. Pod datą 4 VI 1379 [nr 7] wystawił go ówczesny prepozyt w Brixen, pracownik Penitencjarii Apostolskiej, Walter Murner von Munderkingen ${ }^{92}$. Jak zawsze $\mathrm{w}$ tego typu pismach, egzekutor powołał się najpierw na papieską bullę oraz oba dokumenty audytora Mikołaja z Cremony, których incipity i explicity przytoczono, a następnie pod

${ }^{88}$ Przykład takiej bulli zob. AA Wrocław, Dokumenty parafii w Świdnicy, nr 41 (Genua, 20 IV 1386).

89 Tekst dokumentu z wyrokiem liczy ok. 28500 znaków, a należy go jeszcze powiększyć o ok. 3100 znaków, czyli długość tekstu dokumentu z oszacowaniem kosztów procesowych (licząc bez eschatokołu i subskrypcji notarialnej), natomiast tekst bulli papieskiej liczy ok. 8300 znaków.

${ }^{90}$ AP Wrocław, Rep. 66, nr 276 [nr 6], w. 29.

91 Tamże, w. $33 \mathrm{n}$.

92 Walter Murner von Munderkingen (znany także jako Walter ze Strasburga), wieloletni urzędnik Penitencjarii Apostolskiej, posiadacz wielu beneficjów, autor zbioru formularzy stosowanych w Penitencjarii, zmarł w 1407 r.; S. Jäggi, Walter Murner, w: Il Dizionario storico della Svizzera, <https://hls-dhs-dss.ch/it/articles/012849/2009-07-03/> [dostęp: 25.03.2020]; Die Pönitentiarie-Formularsammlung des Walter Murner von Strassburg: Beitrag zur Geschichte und Diplomatik der Päpstlichen Pönitentiarie im 14. Jahrhundert, red. M. Meyer, Freiburg 1979. 
groźbą kar kościelnych nakazał Wernerowi von Czettritz zastosowanie się do wyroku papieskiego trybunału i zapłacenie w ciągu 60 dni klasztorowi zasądzonych 40 florenów. Wszystkim, którzy utrudnialiby wykonanie wyroku, zagrożono cenzurami, od których absolucję Walter Murner zastrzegł sobie lub swojemu przełożonemu. W szczególny sposób napomniany został biskup wrocławski i kapituła katedralna, zapewne dlatego, że sam Werner był kanonikiem wrocławskim, a przedmiot sporu stanowił część uposażenia stołu biskupiego. Cały dyplom spisany został według formularza typowego dla dokumentów egzekutorów i ujęty w formę instrumentu notarialnego, opatrzonego pieczęcią wystawcy ${ }^{93}$.

Tego samego dnia Walter Murner wystawił na prośbę brata Franciszka jeszcze drugi dokument [nr 8], w którym określił łączny koszt wyekspediowania papieskiej bulli egzekucyjnej oraz obu własnych dokumentów na 10 florenów węgierskich i nakazał Wernerowi, by w ciągu 30 dni zapłacił tę sumę klasztorowi. W razie niezastosowania się do niniejszego postanowienia zagroził podobnymi jak poprzednio cenzurami oraz obwarował absolucję identycznymi zastrzeżeniami. Także i ten dyplom miał formę instrumentu notarialnego z pieczęcią Waltera Murnera ${ }^{94}$. Trudno powiedzieć, czy takie pozasądowe powiększenie kosztów procesowych obciążających stronę przegraną było czymś powszechnym i należało do typowych uprawnień egzekutora. Poza tym przypadkiem nigdy więcej nie spotkałem się z podobną sytuacją.

\section{d) proces petytoryjny}

Równolegle z procesem posesoryjnym między zwaśnionymi stronami toczył się proces petytoryjny, czyli postępowanie sądowe mające ustalić, która ze stron ma rzeczywiście prawo własności, a więc w tym konkretnym przypadku - komu przysługuje prawo do czerpania korzyści z rzeki Oławy. Proces toczył się w trzech instancjach, a jego przebieg można poznać dzięki trzem dokumentom z kolejnymi wyrokami audytorów [nr 9, 10,11]. Ze względu na nietypowe cechy tych dokumentów zostaną one omówione zbiorczo nieco dalej.

W I instancji sprawę prowadził audytor Mikołaj z Cremony ${ }^{95}$. Powierzył mu ją papież Grzegorz XI po złożeniu przez klasztor supliki (supplicationis seu commissionis cedula), znanej już z apelacji w sprawie absolutionis ad cautelam i z omówionego wyżej procesu posesoryjnego ${ }^{96}$. Wkrótce po wezwaniu przed sąd Wernera von Czettritz oraz Jana z Kunzendorfu i po pierwszych krokach proceduralnych zmarł papież Grzegorz, co z zasady oznaczało przerwanie wszystkich postępowań w Rocie, ale jego następca Urban VI nakazał audytorom kontynuowanie prowadzonych procesów ${ }^{97}$. Mikołaj z Wołowa, prokurator kanonika Wernera, złożył obszerne pismo procesowe (libellus seu peticio summaria) $7 \mathrm{~V} \mathrm{1378,} \mathrm{a} \mathrm{więc}$ jeszcze przed ogłoszeniem wyroku posesoryjnego (23 VI 1378) ${ }^{98}$. Co ciekawe, libellus w procesie petytoryjnym różni się w istotny sposób od wcześniejszego, złożonego w postępowaniu posesoryjnym. O ile w sporze o posiadanie roszczenia kanonika wrocławskiego dotyczyły praw do korzystania z całej rzeki (tota aqua) na odcinku granicznym między folwarkiem Księże Małe a Bierdzanami, to w procesie petytoryjnym jest już mowa tylko o prawie do połowy rzeki (medietas aque). Ponadto Czettritz nie domagał się już 50 grzywien odszkodowania za poniesione straty. W opisie okoliczności wybuchu konfliktu podano, że kanonik otrzymał folwark od biskupa Przecława w 1360 r. (choć, jak wyżej wspomniano, miało to miejsce w 1370 r.), ale zapewne jest to po prostu pomyłką notariusza. Z dalszego przebiegu procesu znamy tylko kolejne etapy formalne. Na koniec Mikołaj z Cremony 13 V 1379 ogłosił wyrok, w którym uwolnił klasztor od wszystkich roszczeń Wernera i skazał przegranego na zapłacenie kosztów sądowych $^{99}$. Na razie jednak klasztor nie zabiegał o ich oszacowanie. Przed trybunałem Roty kanonika

${ }^{93}$ AP Wrocław, Rep. 66, nr 277 [nr 7] (4 VI 1379).

94 Tamże, nr 278 [nr 8] (4 VI 1379).

95 Proces w I instancji przedstawiony jest w pierwszym dokumencie z 16 II 1383; tamże, nr 299 (298) [nr 9].

${ }^{96} \mathrm{~W}$ dokumencie z wyrokiem I instancji procesu petytoryjnego suplika ta (commissio) została w całości przytoczona. Nie licząc błędów przepisywania, jest ona identyczna jak w dokumencie z 4 III 1377 [nr 2], a ponadto suplika ta została zrelacjonowana (napisana w mowie zależnej) niemal co do słowa w dokumencie z wyrokiem w procesie posesoryjnym z 23 VI 1378 [nr 3 ].

97 AP Wrocław, Rep. 66, nr 299 (298) [nr 9], w. 23-25.

98 Tamże, w. 26-45. Jak już była o tym mowa, wyjątkowo znamy datę tego libellusa, zob. s. 41.

99 AP Wrocław, Rep. 66, nr 299 (298) [nr 9], w. 80-86. 
Wernera reprezentował najpierw prokurator Mikołaj z Wołowa, a później jego pełnomocnikiem został stryj Bartłomiej von Czettritz, kanonik we wrocławskiej kolegiacie Świętego Krzyża ${ }^{100}$, przed sądem występował zaś jego substytut Branchino Besozzi z Mediolanu. Stronę klasztorną cały czas reprezentował mistrz Giso Katzmann, substytut prokuratora Jana Goswinowica. Podobnie jak w procesie posesoryjnym, Giso zjawiał się na każdej rozprawie, natomiast Branchina widzimy w sądzie przez większość procesu, ale nie stawił się na ostatnich rozprawach i wyrok został ogłoszony zaocznie.

Kanonik Werner złożył apelację od niekorzystnego orzeczenia Mikołaja z Cremony i sprawa trafiła przed doktora dekretów Roberta de Stratton. W dokumencie zawierającym wyrok audytora Roberta nie przytoczono na początku żadnej supliki-zlecenia (commissio), a jedynie wspomniano o złożonej apelacji. Nieco dalej inserowano krótki libellus, przedłożony w trakcie procesu przez stronę klasztorną. Jego treść sprowadzała się do prośby do Roberta de Stratton, by potwierdził prawidłowość wyroku Mikołaja z Cremony z I instancji ${ }^{101}$. Orzeczenie na korzyść klasztoru zostało ogłoszone 16 III 1380. Papieski sędzia potwierdził wyrok swojego poprzednika i skazał kanonika Wernera na zapłatę kosztów procesowych (na razie jeszcze nie oszacowanych) ${ }^{102}$. Z opisu przebiegu procesu w II instancji widać, że Giso Katzmann, pełnomocnik krzyżowców, był obecny na wszystkich rozprawach, natomiast prokurator Czettritza, Branchino Besozzi z Mediolanu, nie stawił się w sądzie ani razu! W tej sytuacji postępowanie toczyło się zaocznie, co stawiało wrocławskiego kanonika w niekorzystnej sytuacji procesowej i prowadziło do zasądzenia wyroku kontumacyjnego. Nie dziwi też stosunkowo szybki przebieg procesu w II instancji.

Również od tego wyroku Czettritz złożył apelację i papież powierzył sprawę audytorowi Bertrandowi d'Alagno, biskupowi elektowi Famagusty ${ }^{103}$. Kanonika Wernera w dalszym ciągu reprezentował prokurator Branchino Besozzi, ale dość szybko w jego imieniu zaczął występować substytut Jan syn Szymona $^{104}$. Krzyżowców cały czas reprezentował Giso Katzmann z Fritzlaru. Nie znamy dokładnie chronologii procesu, ale w pewnym momencie - pod nieobecność pełnomocnika strony klasztornej - audytor przeniósł postępowanie do kraju (remissio ad partes), gdzie przesłuchano świadków i odesłano ich zeznania do Rzymu. Później jednak papież nakazał - niewątpliwie wskutek zabiegów Gisona Katzmanna - powrócić do procedowania od momentu przed odesłaniem sprawy ad partes, a więc zeznania świadków uznano za zbędne ${ }^{105}$. Najwyraźniej remissio ad partes była przyczyną znacznego wydłużenia postępowania, bo ostatecznie wyrok został wydany przez audytora Bertranda dopiero 14 I $1383^{106}$. Pod koniec procesu zmienili się też pełnomocnicy stron. Prokuratorem krzyżowców został Piotr z Piotrowic, brat z konwentu św. Macieja, a przed sądem Roty zastępował go substytut Jakub Steube ${ }^{107}$, natomiast nowym substytutem Branchina z Mediolanu został mistrz Antoni z Parmy. Choć podczas całego postępowania w III instancji wszyscy prokuratorzy sumiennie pojawiali się na rozprawach, to podobnie jak w I instancji pełnomocnik Wernera nie stawił się na ostatnich posiedzeniach sądu i wyrok został ogłoszony pod jego nieobecność. Bertrand d'Alagno zatwierdził orzeczenie Roberta de Stratton, co oznaczało ostateczne zwycięstwo konwentu św. Macieja w sporze z Czettritzem i potwierdzenie praw klasztoru do korzystania z rzeki Oławy w dobrach Bierdzany.

Przedstawiony tu przebieg procesu petytoryjnego $\mathrm{w}$ trzech kolejnych instancjach znamy z trzech dokumentów, zawierających kolejne wyroki audytorów papieskich [nr 9, 10, 11]. Co ciekawe, dokumenty te nie były wystawiane bezpośrednio po ogłoszeniu każdej sententia diffinitiva, ale wszystkie

${ }^{100}$ Bartłomiej poświadczony jest jako stryj Wernera i kanonik w kolegiacie Świętego Krzyża w dokumencie z 1383 r.; tamże, nr 304 (303) [nr 14]; zob. też C. Kuchendorf, Das Breslauer Kreuzstift, s. 79.

101 AP Wrocław, Rep. 66, nr 298 (297) [nr 10] (16 II 1383), w. 14-19.

102 Tamże, w. 55-63.

103 Opis procesu w: AP Wrocław, Rep. 66, nr 297 (296) [nr 11] (16 II 1383). Bertrando d'Alagno pochodził ze szlacheckiej rodziny z Amalfi, bp Famagusty (na Cyprze), bp Gubbio (od 1391), abp Amalfi (od 1401); zob. M. Camera, Istoria della città e costiera di Amalfi, t. 1, Napoli 1836, s. 254 n.; C. Eubel, Hierarchia catholica, t. 1, s. 85, 242.

${ }_{104}$ W 1381 r. Branchino został biskupem Bergamo; zob. przyp. 84.

105 AP Wrocław, Rep. 66, nr 297 (296) [nr 11], w. 36-38, 44 n.

106 Tamże, w. 56-61.

107 Jakub Steube, posiadacz kilku beneficjów na Śląsku, potem audytor Roty; zob. G. Schindler, Das Breslauer Domkapitel, s. $354 \mathrm{n}$. 
trzy wystawiono równocześnie tego samego dnia - 16 II 1383, po ostatecznym zakończeniu procesu w Rocie ${ }^{108}$. Wydaje się zresztą, że nie był to wyjątkowy sposób postępowania ${ }^{109}$. Najwyraźniej klasztor nie był zainteresowany uzyskaniem pisemnego potwierdzenia swoich roszczeń, dopóki werdykt sądu mógł ulec zmianie na korzyść kanonika Wernera. Z tego samego powodu krzyżowcy z Czerwoną Gwiazdą nie prosili o otaksowanie kosztów procesowych na poszczególnych etapach postępowania ${ }^{110}$. Dopiero po wydaniu wyroku przez Bertranda d'Alagno skierowali do papieża suplikę, by ów audytor określił koszty sądowe oraz wystawił dokumenty dla wszystkich trzech instancji. Wskazano przy tym, że w ciągu minionych lat audytor Mikołaj z Cremony opuścił Kurię Rzymską, a Robert de Stratton zmarł. Suplika ta (czyli commissio) została przytoczona w końcowej części każdego z trzech dokumentów, tuż po tekstach wyroków ${ }^{111}$. Na podstawie posiadanych akt $\mathrm{z}$ całego procesu notariusze Bertranda przygotowali więc trzy dokumenty z opisem postępowania i sentencjami wydanymi w kolejnych instancjach. Bertrand d'Alagno oszacował też koszty procesowe w poszczególnych instancjach, odpowiednio na 75, 42 i 102 floreny. Kwoty powyższe, jak zawsze, ustalono na podstawie oświadczenia prokuratora Piotra $\mathrm{z}$ Piotrowic, potwierdzonego osobiście złożoną przysięgą. Informację o kosztach zamieszczono w ostatnim z dokumentów z 16 lutego. Wszystkie dyplomy miały typową formę instrumentów publicznych, opatrzonych pieczęcią audytora Bertranda.

\section{e) postępowanie egzekucyjne po procesie petytoryjnym}

Zgodnie z tym, co zostało już przedstawione przy okazji procesu posesoryjnego, kolejnym krokiem było postępowanie egzekucyjne. Bullą z 9 V 1383 [nr 12] Urban VI wyznaczył na egzekutorów opatów wrocławskich klasztorów NMP na Piasku i św. Wincentego na Ołbinie oraz dziekana kolegiaty Świętego Krzyża we Wrocławiu ${ }^{112}$. Podobnie jak we wcześniejszej bulli tego typu, w papieskim piśmie przedstawiono spierające się strony i przedmiot sporu, a następnie w bardzo dużym skrócie przebieg postępowania we wszystkich trzech instancjach. Informując o kolejnych wyrokach, nie podawano dat ich ogłoszenia. Jak zawsze, bulla kończy się dyspozycją, w której papież nakazuje egzekutorom dopilnowanie wykonania wyroku i wypłacenia przez Wernera von Czettritz zasądzonej kwoty. Następny etap miał już miejsce w kraju, na Śląsku. Gdy wszystkie dokumenty dotarły do Wrocławia, konwent św. Macieja zwrócił się do Jana, opata klasztoru Panny Marii na Piasku, jednego z wyznaczonych egzekutorów. Wypełniając zlecony mu obowiązek, opat Jan 25 VII 1383 wystawił dokument [nr 13], w którym nakazał Wernerowi von Czettritz, by zastosował się do wyroku Roty i w ciągu 70 dni zapłacił klasztorowi 219 florenów kosztów procesowych lub uzgodnił z konwentem warunki spłaty zadłużenia' ${ }^{113}$. Wszystkim, którzy utrudnialiby wykonanie wyroku, zagrożono cenzurami kościelnymi, w szczególny sposób napominając biskupa wrocławskiego i kapitułę. Jak zwykle w takich pismach, wystawca powołał się na papieską bullę [nr 12] i wyrok audytora Bertranda z III instancji [nr 11], których incipity

${ }^{108}$ Fakt wystawienia dokumentu z wyrokiem w I instancji po niemal 4 latach od jego wydania zdaje się dowodzić istnienia archiwum Roty i przechowywania w nim materiałów z zakończonych już postępowań przed konkretnym audytorem. W przeciwnym razie zwycięska strona starałaby się uzyskać dokument z wyrokiem zaraz po orzeczeniu audytora. Nie można oczywiście zapominać, że w niniejszej sprawie trwały jeszcze apelacje.

$109 \mathrm{Na}$ przykład w procesie posesoryjnym o dziesięciny między klasztorem św. Wincentego na Ołbinie a plebanem w Kamieniu w trzech instancjach zapadły kolejno wyroki audytorów: 16 V 1382, 1 XII 1382 i ostateczny 13 III 1383 (koszty procesowe otaksowano tu 1 IV 1383), po czym dopiero 10 IV 1383 oszacowano koszty procesu w I instancji i wtedy też audytor wystawił dokument zawierający wyrok z $16 \mathrm{~V}$ 1382. Z nieznanych powodów nie oszacowano kosztów II instancji, a audytor od razu 1 XII 1382 wystawił dokument z wyrokiem; AP Wrocław, Rep. 135, t. 376 [D 90 II], f. 183v-189r (kopia dokumentu egzekutora z 2 IX 1383); oryginalne dokumenty trzech audytorów, bulla egzekucyjna i dyplom egzekutora (Rep. 67, nr 561, 562, 563, 566, 572) zaginęły w czasie II wojny światowej.

110 Postępowanie takie nie było niczym niezwykłym. W procesie między klasztorem św. Wincentego we Wrocławiu a plebanem w Kamieniu od wydania wyroku (w procesie posesoryjnym) w I instancji (16 V 1382) do otaksowania kosztów procesowych (10 IV 1383) minął niemal rok; zob. AP Wrocław, Rep. 135, t. 376 [D 90 II], f. 184v-185r; oryginalny dokument AP Wrocław, Rep. 67, nr 563, zaginął w czasie II wojny światowej.

111 AP Wrocław, Rep. 66, nr 299 (298) [nr 9], w. 87-92; nr 298 (297) [nr 10], w. 64-70; nr 297 (296) [nr 11], w. 62-67.

112 Tamże, nr 300 (299) [nr 12]

113 Tamże, nr 301 (300) [nr 13]. 
i explicity przytoczono. Formularz dokumentu opata Jana jest bardzo podobny do analogicznego dokumentu Waltera Murnera z 1379 r. [nr 7].

W zasadzie w tym miejscu cała historia sporu mogłaby się zakończyć, ale kanonik Werner von Czettritz miał problemy ze spłatą tak wysokiej sumy. Konieczne okazało się wsparcie rodziny. Za Wernera poręczył więc jego brat Herman, od niedawna właściciel zamku Konradów ${ }^{114}$. Dokumentem wystawionym w swoim zamku 25 IX 1383 [nr 14a] zobowiązał się on, że zapłaci należne 219 florenów w dwóch ratach: pierwszą połowę na św. Marcina (11 XI 1383), a drugą w dzień św. Walpurgi (1 V 1384). Gdyby zaś owa kwota nie została uiszczona w wyznaczonych terminach, to rycerz Herman zgodził się podporządkować w tej sprawie jurysdykcji kościelnej. W celu dopełnienia niezbędnych formalności mianował swoim pełnomocnikiem stryja Bartłomieja von Czettritz, kanonika w kolegiacie Świętego Krzyża ${ }^{115}$. Następnie Bartłomiej, w obecności Jana, mistrza klasztoru św. Macieja, oficjalnie złożył w imieniu Hermana zobowiązanie o powyższej treści, a egzekutor Jan, opat klasztoru na Piasku, przyjął je i zatwierdził dokumentem wydanym we Wrocławiu 3 X 1383 [nr 14] ${ }^{116}$. Pięć dni później Herman von Czettritz ratyfikował zobowiązanie złożone przed egzekutorem przez stryja Bartłomieja, co spisano w formie instrumentu publicznego [nr 14b] ${ }^{117}$. Warto w tym miejscu zauważyć, że między dokumentem egzekutora z 3 października a instrumentem z 8 dnia tegoż miesiąca istnieje nieusuwalna sprzeczność chronologiczna, gdyż późniejsza ratyfikacja została transumowana we wcześniejszym o pięć dni dokumencie, również mającym formę instrumentu notarialnego ${ }^{118}$.

\section{Wnioski}

Przedstawiony tu spór sądowy o prawo do korzystania z rzeki Oławy jest przykładem procesu przed średniowiecznym trybunałem Roty Rzymskiej w sprawie własnościowej. Z natury rzeczy spór sądowy o prawo własności był dłuższy i droższy niż zwykły proces o prebendę. Mimo braku dokładnych informacji o początkach postępowania w Rocie, można w przybliżeniu określić czas jego trwania. Konflikt między Wernerem von Czettritz a konwentem św. Macieja wybuchł w lutym 1371 r. Po ponad półtorarocznym procesie we Wrocławiu przed papieskim sędzią delegowanym Janem z Kunzendorfu proces przeniósł się do Roty ${ }^{119}$. Nie znamy momentu wszczęcia postępowania w Awinionie, bo nie jest znana data papieskiej commissionis (supliki-zlecenia) powierzającej sprawę audytorowi Mikołajowi z Cremony, ale wiadomo, że apelacja konwentu do Stolicy Apostolskiej nastąpiła po wyroku z 19 VIII 1374 [nr 1]. Postępowanie w sprawie udzielenia absolucji ad cautelam rozpoczęło się jakiś czas przed wrześniem 1376 r., kiedy to Grzegorz XI opuścił Awinion. Orientacyjnie można przyjąć, że proces w Rocie rozpoczął się w drugiej połowie 1375 lub na początku 1376 r. Ostateczne udzielenie absolucji nastąpiło zapewne jesienią 1377 r. ${ }^{120}$ Postępowanie posesoryjne trwało prawdopodobnie od schyłku $1377 \mathrm{r}$.

114 Zamek Konradów (albo Wojaczów, dzisiaj ruina koło wsi Grzędy). Herman von Czettritz nabył ten zamek w 1379 r.; zob. A. Boguszewicz, Corona Silesiae. Zamki Piastów fürstenberskich na poludniowym pograniczu księstwa jaworskiego, świdnickiego i ziębickiego do połowy XIV wieku, Wrocław 2010, s. 214-216.

115 AP Wrocław, Rep. 66, nr 304 (303) (insert z 25 IX 1383 [nr 14a], w. 21-35).

116 Tamże, [nr 14] (3 X 1383).

117 Tamże (insert z 8 X 1383 [nr 14b], w. 37-46).

118 Dokument (instrument notarialny) egzekutora Jana z 3 X 1383 [nr 14] zachował się w oryginale, natomiast prywatny dokument Hermana von Czettritz z 25 września [nr 14a] oraz zatwierdzenie jego obligacji (instrument notarialny) z 8 października [nr 14b] znane są tylko z kopii w tym dokumencie egzekutora. Sprzeczności, jaką jest transumowanie w dokumencie z 3 października pisma o 5 dni późniejszego, nie usunie przyjęcie, że mamy do czynienia z pomyloną w kopii datą, dokument z 8 października jest bowiem zatwierdzeniem czynności wykonanej 5 dni wcześniej. Oba dokumenty, z 3 i 8 października, nawzajem wprost powołują się na siebie i oba są instrumentami notarialnymi. Zapewne dokument z 8 października został spisany 25 września i następnie postdatowany.

119 Na mocy bulli z 21 X 1372 [nr 1a] kanonik Werner przed kwietniem 1373 r. zwrócił się do sędziego Alberta von Schellindorf, formalne zaś postępowanie przed substytutem Janem z Kunzendorfu rozpoczęło się niedługo po 22 IV 1373.

${ }^{120}$ Audytor Mikołaj z Cremony udzielił konwentowi absolucji 4 III 1377 [nr 2], ale potem nastąpiły jeszcze dwie apelacje Wernera. 
do wydania wyroku 23 VI 1378 [nr 3], a więc ok. 6 miesięcy, dokument egzekutora został zaś wystawiony w Rzymie dopiero 4 VI 1379 [nr 7]. Najważniejszy proces, czyli petytoryjny, toczył się przez jakiś czas równolegle do posesoryjnego i podczas tego postępowania $7 \mathrm{~V} 1378$ zostało złożone przez Wernera pismo procesowe. Wyrok w III instancji zapadł 14 I 1383, co zakończyło sprawę w Rocie. Tak więc postępowanie w papieskim trybunale trwało łącznie ponad 7 lat, przy czym wydłużyło się ono o kilka miesięcy z powodu przenosin Kurii do Rzymu. Dokument egzekutora został wystawiony we Wrocławiu o kolejne pół roku później (25 VII 1383 [nr 13]). Licząc od chwili wszczęcia procesu we Wrocławiu, sądowe rozstrzygnięcie sporu o prawo do korzystania z rzeki Oławy zajęło w sumie 10 lat. Warto zauważyć, że wydłużenie sporu wynikło m.in. ze zmiany sądu oraz zabiegów formalnych (np. dwóch apelacji od udzielonej absolucji), a więc z działań stron sporu, a nie z powodu opieszałości Roty.

Tak długi spór sądowy, i to toczony w odległym trybunale, musiał też być kosztowny. Czettritz zapłacił konwentowi w sumie 269 złotych florenów kosztów procesowych ${ }^{121}$, a do tego trzeba doliczyć wydatki samego Wernera. Nie wiadomo, co dokładnie złożyło się na koszty poniesione przez klasztor, ale można przypuszczać, że kanonik wydał na swoje potrzeby porównywalną sumę. Myślę, że łączne wydatki Czettritza można ostrożnie szacować na co najmniej 400 florenów, a prawdopodobnie dużo więcej. W porównaniu do jego dochodów była to kwota bardzo wysoka. Nie wiadomo wprawdzie, ile przynosiła kanonikowi jego prebenda wrocławska, wysokość uposażenia poszczególnych kanonii mogła się bowiem znacznie różnić. Wydaje się, że średni przychód kanoników mógł w tym czasie oscylować wokół 70 florenów rocznie, choć jest to szacunek bardzo przybliżony ${ }^{122}$. Do tego dochodziły jeszcze dystrybucje chórowe dla rezydujących i ewentualne środki dodatkowe (jak np. gratia od biskupa) ${ }^{123}$, jednak dużą część swych dochodów kanonik wydawał przecież na własne utrzymanie ${ }^{124}$. Na podstawie dostępnych źródeł trudno ocenić, czy Czettritz przegrał spór z powodów merytorycznych, czy też wskutek niemożności udźwignięcia kosztów procesu. O kłopotach finansowych może świadczyć częsta zmiana prokuratorów reprezentujących go w sądzie oraz notoryczne niestawiennictwo prokuratora w postępowaniu w II instancji. Jest prawdopodobne, że przeniesienie przez krzyżowców procesu z Wrocławia do Roty, dokonane dzięki zastosowaniu kruczków prawnych, było zabiegiem mającym na celu wykorzystanie przewagi finansowej nad przeciwnikiem. Nie widać też, by klasztor miał problemy z opłacaniem swojego prawnika.

Podsumowując powyższe rozważania, można ocenić wartość, jaką przedstawiają dokumenty związane z procesem w Rocie z punktu widzenia historyka. Najwięcej informacji przynoszą dokumenty audytorów Roty, całościowo ukazujące proces zakończony wyrokiem. Szczególnie cenne dla badacza są - przytaczane zwykle w całości - pierwsza commissio (suplika-zlecenie) oraz libellus pozwanego. Należy jednak pamiętać, że mimo bogactwa szczegółów suplika i libellus podają tylko informacje istotne z punktu widzenia procedury sądowej, a mogą pomijać wiele ważnych dla historyka okoliczności sprawy. Pierwsza commissio w procesie, dająca początek postępowaniu przed audytorem, opowiada o stronach i przedmiocie sporu oraz opisuje okoliczności, które doprowadziły do przeniesienia procesu z kraju przed papieski trybunał. Co istotne, jej celem nie jest przedstawienie wszystkich okoliczności, ale tylko bezpośredniego formalnego powodu apelacji do Stolicy Apostolskiej. W omawianym przypadku

\footnotetext{
${ }^{121}$ Na tę kwotę składa się 219 florenów za proces petytoryjny oraz $40+10$ florenów za wcześniejszy proces posesoryjny.

${ }_{122}$ W 1391 r. we wrocławskiej kapitule katedralnej dokonano zrównania prebend, przyznając każdemu z kanoników po 12 grzywien groszy praskich rocznie, a w 1396 r. podniesiono tę kwotę do 30 grzywien. Można więc przyjąć tę ostatnią wielkość za średni dochód z prebendy. W tym czasie 1 grzywna groszy praskich była warta ok. 2,4 florena; zob. Z. Żabiński, Systemy pieniężne na ziemiach polskich, Wrocław 1981, s. 51 (tabela). W latach 1431-1433 rezydujący na Śląsku kolektor papieski w kolejnych latach przeliczał 1 florena na 26, 27 i 28 groszy praskich, czyli 1 grzywna = 1,85-1,71 florena; zob. M.D. Kowalski, Rationes Iacobini de Rubeis, collectoris in Regno Poloniae (1426-1434). Rachunki Giacomina Rossiego, papieskiego kolektora generalnego w Polsce, z lat 1426-1434, St. Źródł., 49, 2011, s. 82-84.

${ }_{123}$ K. Dola, Wrocławska kapituła, s. 62-64, 91-93; G. Schindler, Das Breslauer Domkapitel, s. $25-27$.

124 Nie wiadomo, by Werner von Czettritz posiadał jeszcze inne beneficjum oprócz kanonii katedralnej; zob. G. Schindler, Das Breslauer Domkapitel, s. 202 n.
} 
była to niezgoda na rozszerzenie delegacji sędziego. Libellus strony przeciwnej ukazuje punkt widzenia przeciwnika procesowego i jego oczekiwania co do werdyktu audytora. Ewentualne kolejne commissiones, również cytowane w całości, dotyczą już samej procedury sądowej, w znacznie mniejszym stopniu wzbogacając wiedzę o procesie ${ }^{125}$. Większą część dokumentu wypełnia opis kolejnych stadiów proceduralnych, pełen formularzowej „waty słownej”. Nawet jednak ten czysto formalny opis pozwala na wyciągnięcie pewnych wniosków o przebiegu postępowania w trybunale. Niestety, zarówno w pierwszej commissio, jak i w opisie procesu z zasady nie ma dat. Wskazówek chronologicznych mogą udzielać jedynie wzmianki o niektórych wydarzeniach, jak w tym przypadku powrót papieży do Rzymu czy zmiana na tronie Piotrowym. Zawsze natomiast podawana jest data ogłoszenia wyroku, a ponadto znana jest także data otaksowania kosztów sądowych ${ }^{126}$. Dokumenty audytorów innego rodzaju niż te zawierające wyroki są znacznie uboższe w informacje, choć i w nich może być zacytowana w całości pierwsza commissio $^{127}$. Ma to szczególne znaczenie w sytuacji, gdy proces przerwano przed wydaniem wyroku.

Jak wyżej wspomniano, najliczniejszą grupę źródeł związanych z procesami w Rocie Rzymskiej tworzą papieskie bulle egzekucyjne, zachowane w dość dużej liczbie dzięki wpisywaniu ich do registrów kancelaryjnych. Niestety, mimo znacznej objętości i pozornego bogactwa treści, pomijają większość informacji z pierwszej commissio i z ewentualnego libellusa, ograniczając się głównie do przedstawienia stron i przedmiotu sporu, a tylko czasem podają więcej szczegółów. Z oczywistych względów jedynie postanowienia wyroku są opisane dokładnie, ale bez podania daty jego ogłoszenia. Należy mieć na uwadze, że sentencję audytora od wystawienia bulli mogło dzielić kilka miesięcy ${ }^{128}$. W sprawach beneficjalnych, najliczniejszych w Rocie, informacje podane w bulli mogą być w wielu przypadkach wystarczające, gdy przed audytora trafiał spór nie mający dłuższej historii w kraju. W skomplikowanych sporach o tytuły własności papieski dokument nie przedstawi nigdy pełnego obrazu. W archiwach odbiorców zachowują się też czasem dokumenty wystawiane przez egzekutorów wyznaczonych przez papieża. Egzekutor zawsze powoływał się na bullę nominacyjną, a następnie na wyrok lub rozporządzenie, którego wypełnienia miał dopilnować. W innych niż sądowe sprawach treść przywoływanych pism podawano zwykle w całości, ale w przypadku bardzo długich dokumentów audytorów i bulli egzekucyjnych przepisywano jedynie ich początek i koniec. W zależności od tego, jak duże fragmenty przepisał notariusz, cenne informacje mogły się zachować lub nie.

Mimo wyjątkowo bogatej dokumentacji konfliktu między krzyżowcami z Czerwoną Gwiazdą a kanonikiem Wernerem wielu aspektów sporu - także tych podstawowych - nie da się wyjaśnić. Nie wiadomo dokładnie, kiedy rozpoczął się proces w Rocie, choć i tak szczegóły dotyczące postępowania przed Janem z Kunzendorfu pozwalają ustalić przybliżony termin. Nie wiadomo, jaki był stosunek biskupa do toczącego się sporu, a przecież folwark wraz z przysługującymi mu prawami należał do uposażenia stołu biskupiego, a kanonik Werner otrzymał go tylko w czasowe użytkowanie. O ile w procesie we Wrocławiu prawa katedry były wielokrotnie przypominane, o tyle w dokumentach audytorów nie wspomniano o nich ani razu. Nawet odtworzenie początkowej fazy konfliktu o prawa do rzeki Oławy wymagało wykorzystania danych z kilku różnych dokumentów. Jak niemal zawsze w średniowiecznych źródłach sądowych, nieznane są argumenty stron ani przedstawiane dowody. Nie jest więc znana przyczyna porażki Czettritza. Czy spowodowały ją względy finansowe albo czysto formalne, czy może klasztor posiadał stosowne przywileje na poparcie swoich roszczeń?

125 W omawianym przypadku jedna commissio nakazywała połączyć apelację konwentu w sprawie absolucji ze sprawą główną, czyli osądzeniem tytułu własności. Jedna z ostatnich commissionum nakazywała audytorowi z III instancji wystawić odpowiednie dokumenty dla instancji wcześniejszych (zob. wyżej).

126 Była to bowiem ostatnia czynność procesowa, a więc data ustalenia kosztów jest datą wystawienia dokumentu zawierającego wyrok lub osobnego dokumentu dotyczącego wyłącznie taksacji.

127 Zob. np. ZDKK, t. 1, nr 88; KDWlkp., t. 9, nr 1111, 1143, 1184.

${ }^{128} \mathrm{~W}$ omawianym procesie były to trzy miesiące. W procesie między klasztorem św. Wincentego we Wrocławiu a plebanem w Kamieniu od wydania wyroku (w procesie posesoryjnym) w III instancji (1 IV 1383) do bulli egzekucyjnej (28 V 1383) minęły dwa miesiące; zob. AP Wrocław, Rep. 135, vol. 376 [D 90 II], f. 184r-185r; oryginalne dyplomy AP Wrocław, Rep. 67, nr 563 i 572 zaginęly w czasie II wojny światowej. 
Zwykle liczba zachowanych źródeł wytworzonych przy okazji sporu toczonego w Rocie jest znacznie mniejsza niż w omawianym tu procesie klasztoru św. Macieja przeciwko kanonikowi Wernerowi. Uzyskany obraz wydarzeń będzie więc siłą rzeczy tym bardziej niepełny. Korzystając z dokumentów związanych z procesem sądowym w Rocie Rzymskiej, należy zawsze pamiętać, że wiele ważnych wiadomości, niekiedy kluczowych, pozostaje na zawsze nieznanych.

\section{Aneks}

Wykaz dokumentów dotyczących sporu Wernera von Czettritz z klasztorem św. Macieja

1. Wrocław, 19 VIII 1374 - dokument z wyrokiem Jana z Kunzendorfu

1a. Awinion, 21 X 1372 - bulla Grzegorza XI (insert)

1b. Wrocław, 22 IV 1373 - Albert von Schellendorf subdeleguje Jana z Kunzendorfu (insert)

2. Rzym, 4 III 1377 - audytor Mikołaj z Cremony udziela konwentowi absolucji ad cautelam

3. Rzym, 23 VI 1378 - dokument z wyrokiem Mikołaja z Cremony w procesie posesoryjnym

4. Wrocław, 7 X 1378 - umowa kapituły zakonnej z mistrzem Janem Sebinwirtem

5. Rzym, 23 III 1379 - taksacja kosztów procesu posesoryjnego

6. Rzym, 11 IV 1379 - bulla egzekucyjna Urbana VI do procesu posesoryjnego

7. Rzym, 4 VI 1379 - dokument egzekutora Waltera Murnera

8. Rzym, 4 VI 1379 - egzekutor Walter Murner taksuje koszty dokumentów

9. Rzym, 16 II 1383 - publikacja wyroku Mikołaja z Cremony (proces petytoryjny, I instancja)

10. Rzym, 16 II 1383 - publikacja wyroku Roberta de Stratton (proces petytoryjny, II instancja)

11. Rzym, 16 II 1383 - dokument z wyrokiem Bertranda d'Alagno (proces petytoryjny, III instancja)

12. Rzym, 9 V 1383 - bulla egzekucyjna Urbana VI do procesu petytoryjnego

13. Wrocław, 25 VII 1383 - dokument egzekutora Jana, opata klasztoru NMP na Piasku

14. Wrocław, 3 X 1383 - opat Jan, egzekutor, zatwierdza zobowiązanie Hermana von Czettritz w sprawie spłaty długu Wernera

14a. zamek Konradów, 25 IX 1383 - Herman von Czettritz ustanawia stryja Bartłomieja von Czettritz swoim pełnomocnikiem (insert)

14b. zamek Konradów, 8 X 1383 - Herman von Czettritz ratyfikuje zobowiązanie do zapłaty długu (insert, postdatowany)

\section{Canon Werner von Czettritz's dispute with St Matthew Monastery in Wroclaw - a lawsuit before the Roman Rota and its source documents}

Summary: In 1373-1383, a court trial took place between the monastery of St Matthias in Wrocław belonging to the Brethren (Knights) of the Cross with the Red Star and a cathedral canon Werner von Czettritz over the right to use the Olawa River. The case was tied up in complicated court proceedings first in Wrocław before a papal delegated judge, and then (1375-1383) before the Apostolic Tribunal of the Roman Rota, where the possessory and petitiory trials took place. Unusually abundant documentation has survived - as many as fourteen long documents (eighteen with the inserts). The author reconstructs the course of the trial and discusses the documents related to it, both those issued by the Rota (documents of the auditors with verdicts), and those related to the enforcement proceedings; then, he analyses the value of various types of documents for historical research. Especially valuable for scholars are the documents issued by the auditors, in particular an included supplication (supplicationis sive commissionis cedula) of the plaintiff and the pleading (libellus) of the defendants. The papal enforcements bulls, which make the most numerous group of preserved documents of the lawsuits, despite being very large, are less useful as they focus on the formal aspects of the trial and the richness of their content is illusory. All documents of the Rota and those of the enforcement proceedings include only the information essential for the court proceedings, omitting many facts important for historians. The picture of the legal dispute is rarely complete. Also in the canon's lawsuit against the monastery, it is not clear why Werner lost the suit before the Rota - whether for substantive reasons or unable to pay the high costs of a lengthy trial. 
Nota o autorze: Marek Daniel Kowalski, dr hab., prof. UJ, profesor historii średniowiecznej na Wydziale Historycznym Uniwersytetu Jagiellońskiego w Krakowie. W latach 2008-2018 był także zatrudniony w Instytucie Historii im. Tadeusza Manteuffla PAN, w Zakładzie Badań Źródłoznawczych i Edytorstwa. Specjalizuje się w historii Kościoła średniowiecznego w Polsce (XIV-XV w.), kontaktach Polski ze Stolicą Apostolską, dyplomatyce i skarbowości papieskiej. Jest autorem edycji źródeł proweniencji papieskiej z XIV i XV w.

Author: Marek Daniel Kowalski is a professor of medieval history at the Jagiellonian University in Kraków. In 2008-2018, he was also employed at the Tadeusz Manteuffel Institute of History, Polish Academy of Sciences, in the Department of Source Criticism and Editing. He specialises in the history of Polish medieval Church $\left(14^{\text {th }}-15^{\text {th }}\right.$ cc. $)$, relationships between Poland and the Holy See, papal diplomatics and papal fiscal system. He is the editor of the documents of papal provenance $\left(14^{\text {th }}\right.$ and $\left.15^{\text {th }} \mathrm{cc}.\right)$.

Instytut Historii Uniwersytetu Jagiellońskiego

ul. Gołębia 13

31-007 Kraków

e-mail: marek_daniel.kowalski@uj.edu.pl

\section{Bibliografia}

Bukowska-Gorgoni Ch., Causae Polonae coram Sacra Romana Rota. XV-XVII saec. Explanatio processuum et regesta documentorum, Roma 1995

Hilling N., Die römische Rota und das Bistum Hildesheim am Ausgange des Mittelalters (1464-1513). Hildesheimische Prozeßakten aus dem Archiv der Rota zu Rom, Münster 1908

Hoberg H., Inventario dell'archivio della Sacra Romana Rota (sec. XIV-XIX), oprac. J. Metzler, Città del Vaticano 1994

Kowalski M.D., Rationes Iacobini de Rubeis, collectoris in Regno Poloniae (1426-1434). Rachunki Giacomina Rossiego, papieskiego kolektora generalnego w Polsce, z lat 1426-1434, St. Źródł., 49, 2011, s. 62-96

Nachtman W., Trybunat Roty Rzymskiej. Historia, organizacja, postepowanie, Lublin 1957

Salonen K., Papal Justice in the Late Middle Ages. The Sacra Romana Rota, London-New York 2016

Schindler G., Das Breslauer Domkapitel von 1341-1417. Untersuchungen über seine Verfassungsgeschichte und persönliche Zusammensetzung, Breslau 1938

Starnawska M., Między Jerozolima a Łukowem. Zakony krzyżowe na ziemiach polskich w średniowieczu, Warszawa 1999

Uruszczak W., Spoliatus ante omnia restituendus. Znaczenie prawa kanonicznego w rozwoju ochrony posiadania, w: Possessio ac iura in re. Z dziejów prawa rzeczowego, red. M. Mikuła, W. Pęksa, K. Stolarski, Kraków 2012, s. 17-24

Wójcik M.L., Pieczęcie rycerstwa ślaskiego w dobie przedhusyckiej, t. 1-2, Kraków-Wrocław 2018 